\title{
قراءة توحيدية في حديث افتراق الأمة
}

عامر الحافي

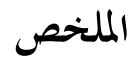

أمام العديد من القراءات التفريقية السائدة لحديث افتراق الأمة، التي تكرس الفرقة وتشيع الفتنة والصراع بين

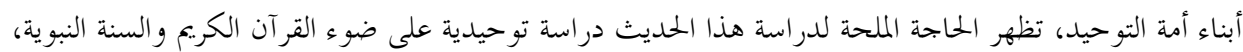
ومحاولة الخروج بقراءة معاصرة للعلاقة بين الفرق الإسلامية تعظم الجوامع وتبحث عن الكلمة السواء. فادعاء تفرد

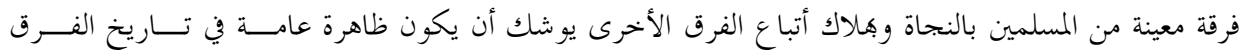
الإسالمية.

وأمام هذه الإشكالية يسعى هذا البحث إلى دراسة مرتبة الحديث والمعاني الأساسية لمتنه، وتنــاول الفـــرق

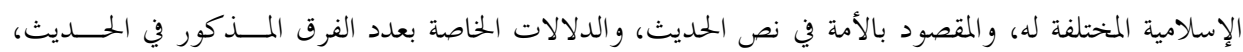
وإمكانية تعيين الفرقة الناجية، وخطورة القراءة التفريقية في دراسة الفرق الإسلامية، وأبرز ملامح القراءة التوحيدية في هذه الدراسة الكلمات المفتاحية: الفرقة الناجية، القراءة التوحيدية، القراءة التفريقية.

\section{Abstract}

Unlike most of the prevailing readings of the "Hadith of sects of Muslim Ummah", which establishes a discord and conflict that disturbs the unity of Muslims, there is an urgent need to study this Hadith differently, to give a better understanding of the relationship between Muslim sects; an understanding that maximizes denominators and common word. The claim of uniqueness of a certain sect to be right and to consider others to be wrong and deserves hell, is about to be a general phenomenon in the history of Muslim sects.

This paper aims to explain the reliability of the Hadith and its meanings, the way in which the Hadith addresses the difference between the various Muslim groups, the indicators related to the number of groups, the possibility of identifying the right one, the dangers of the sectarian reading of the Hadith, and main features of a monotheistic reading of the study of Muslim sects.

Keywords: saved sect, sectarian reading, monotheistic reading,

استاذ الأديان المساعد، كلية الشريعة، جامعة آل البيت، الأردن. البريد الإلكتروني: yahoo.com.

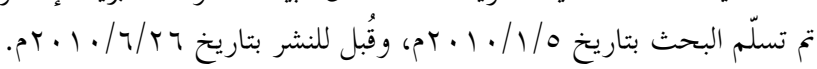




\section{مقدمة:}

أمام العديد من أنماط الاختلافات الإنسانية، اتخذ الاختلاف الديني -علــى مــرّ

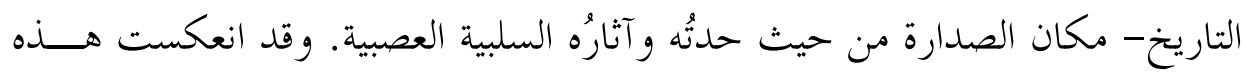

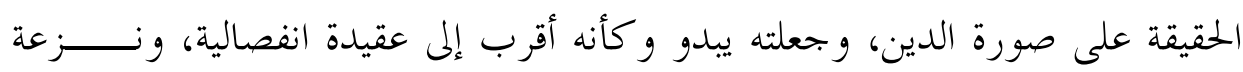

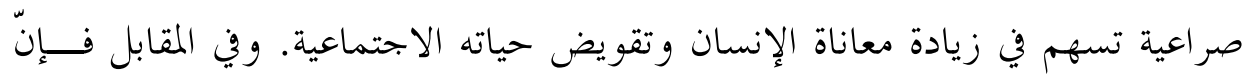

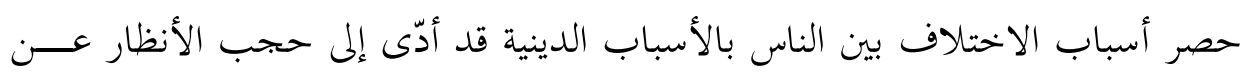

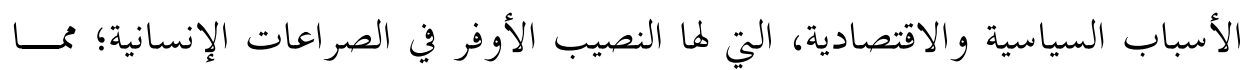
أدى إلى تضليل كثير من أتباع الفرق عن معرفة الأسباب الموضوعية للاختلاف، وزادياد من حدة الصراع بينهم.

وفي الوقت الذي أخذ فيه أتباع الفرق والمذاهب الدينية لــــى أهـــل الكتـــاب

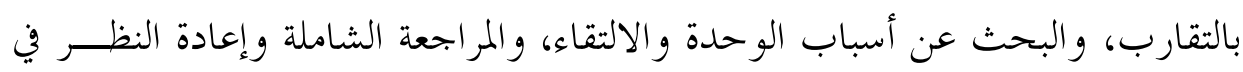

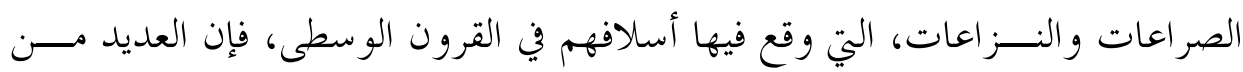

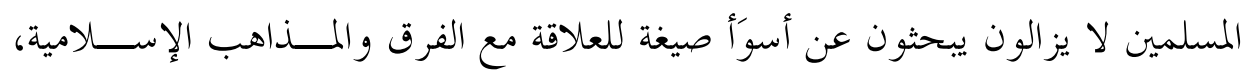

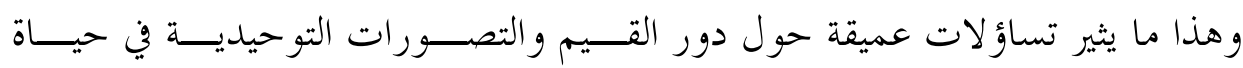

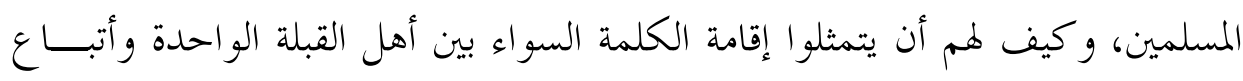
ديانة التوحيد؟ على الرغم من الإشكالات العديدة التي تعترض صحة رواية حديث افتراق الأمة،

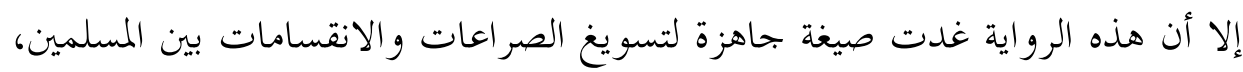

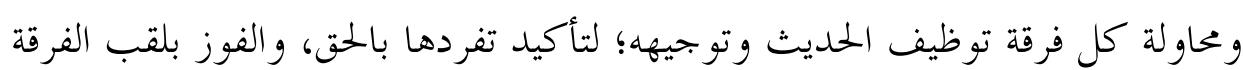

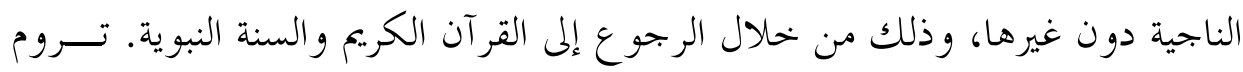

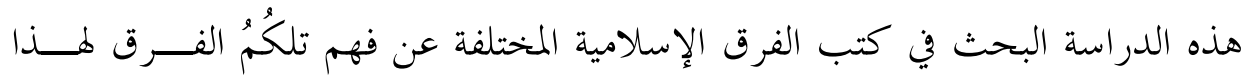

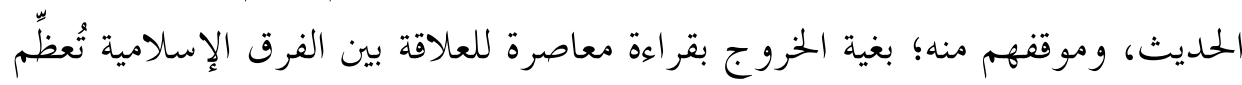

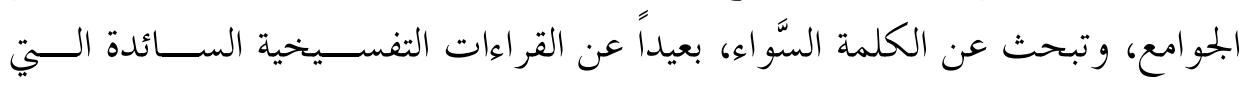
تكرس الفرقة، وتشيع الفتنة والصراع بين أبناء الأمة الواحدة. 


\section{ا ـ روايات الحديث في كتب أهل السنة:}

عن أبي إ أميت ستفترق على اثنتين و سبعين فرقة، فتهلك إحدى وسبعون وتخلص

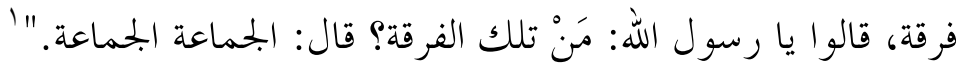

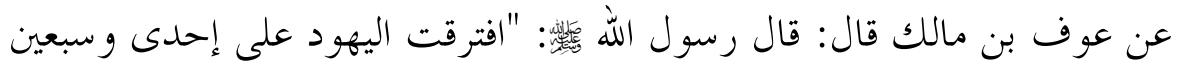
فرقة؛ فواحدة في الجنة، وسبعون في النار . و افترقت النصارى على ثنتين وسبعين فرقة؛

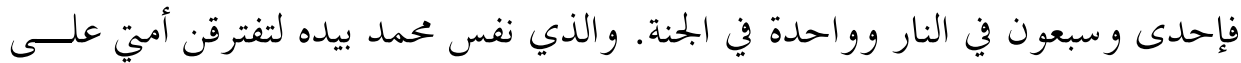

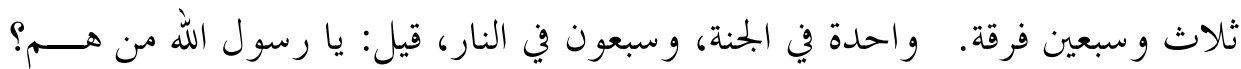
قال: الجماعة.

عن عبد الله بن عمرو قال: قال رسول الله

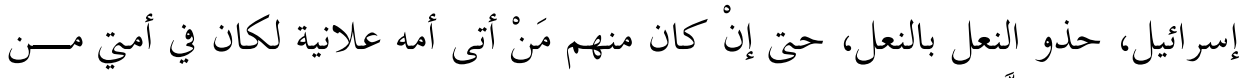

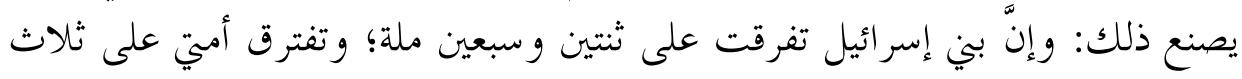

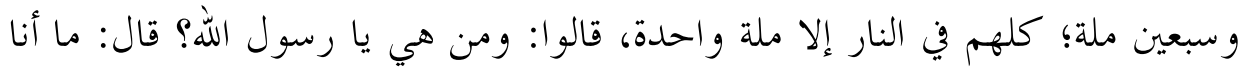

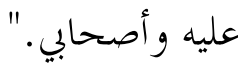

وقد روى الترمذي هذه الرواية وقال: "هذا حديث حسن غريـــب، مفســــ لا نعرفه. " ن

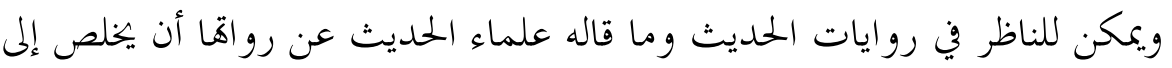

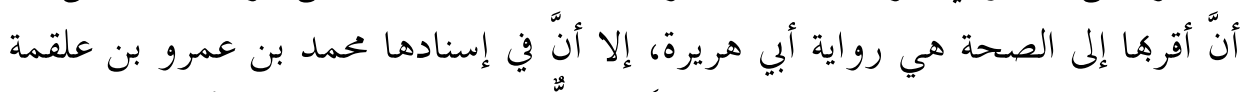

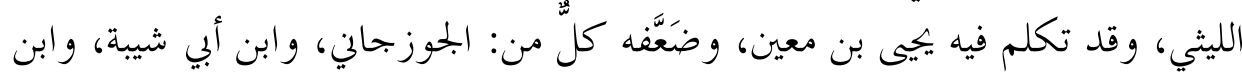

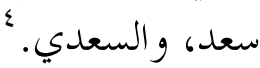

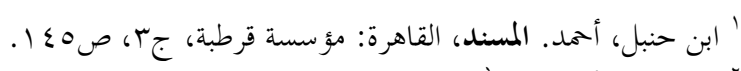

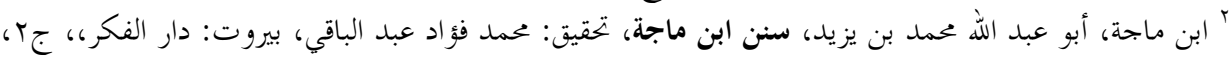

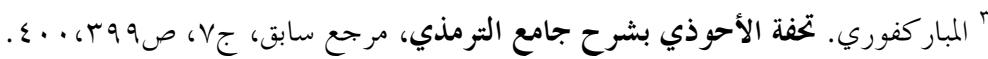

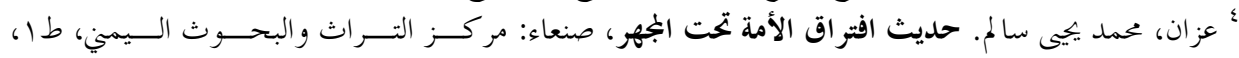




\section{Y. . حديث افتراق الأمة في كتب الفرق الإسلامية الأخرى:}

إلى جانب كتب أهل السنة التي روت حديث اختلاف الأمة، فقد روي الحديث

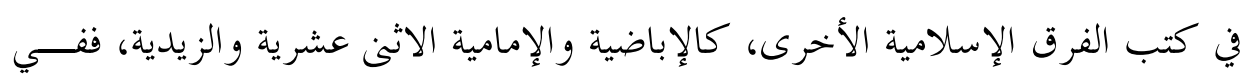

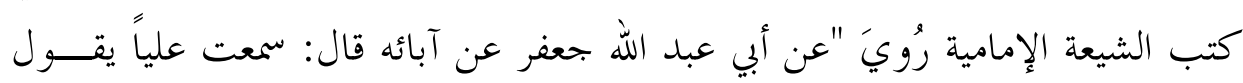

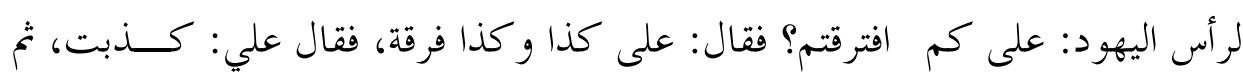

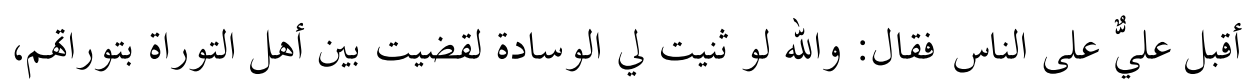

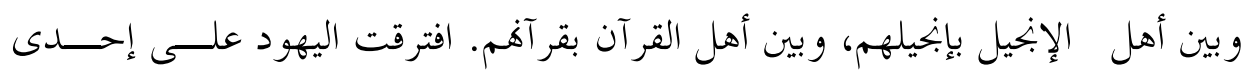

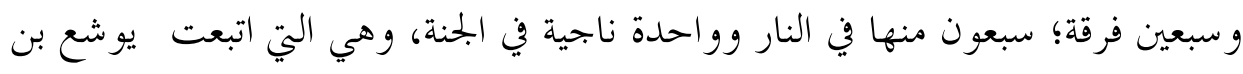

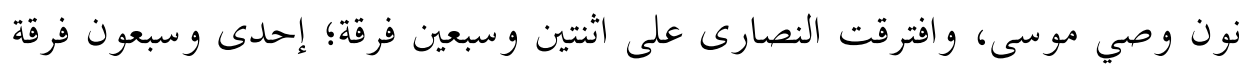

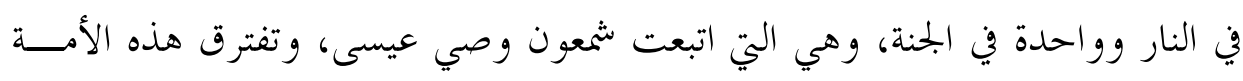

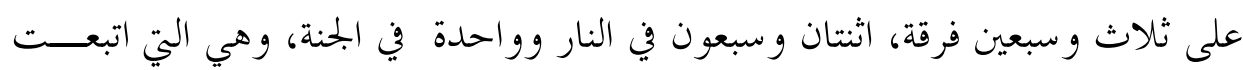

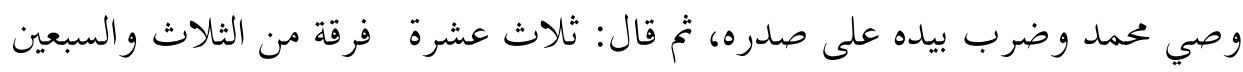

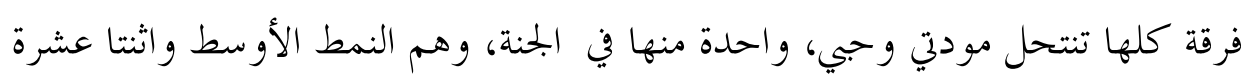
في النار .

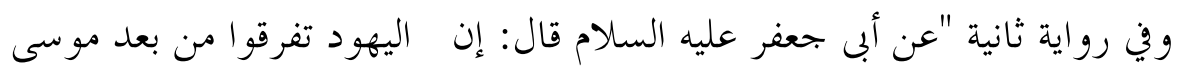

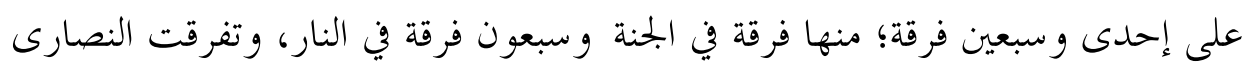

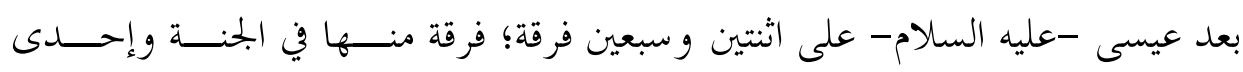

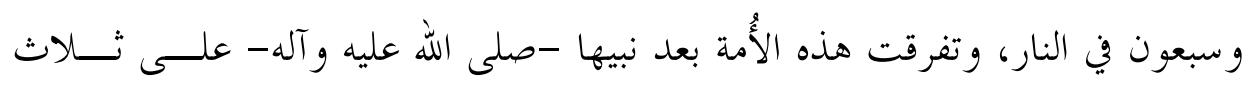

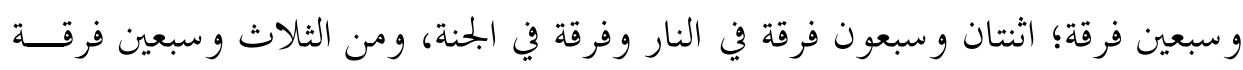

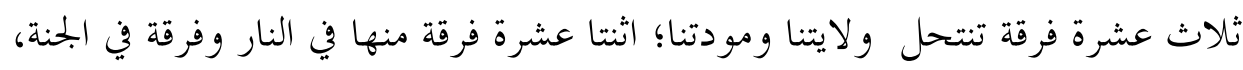

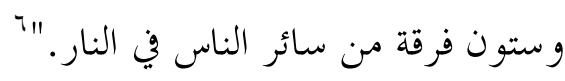

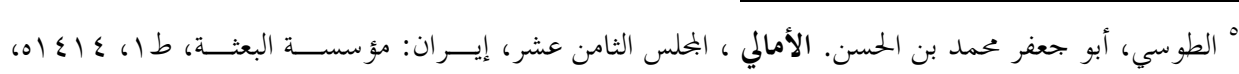

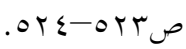

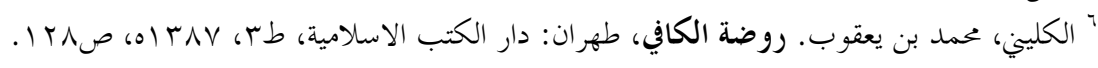




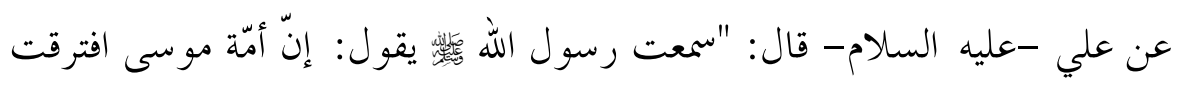

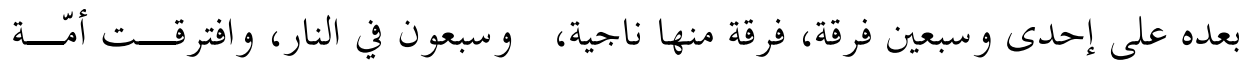

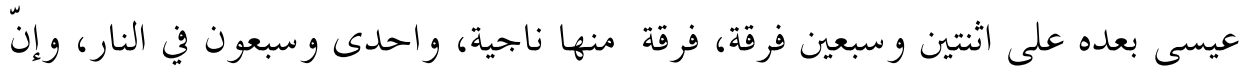

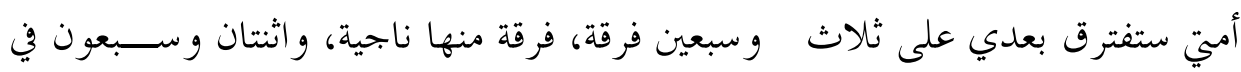
النار

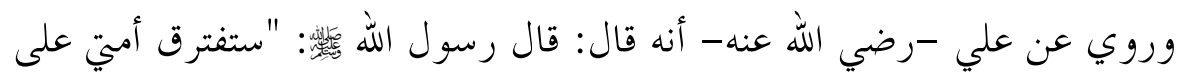

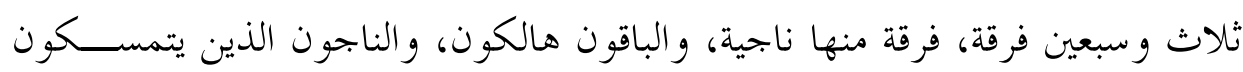

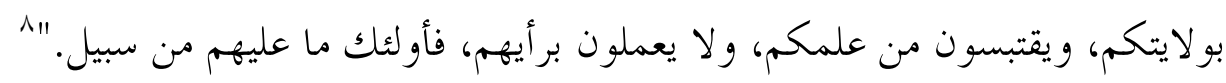

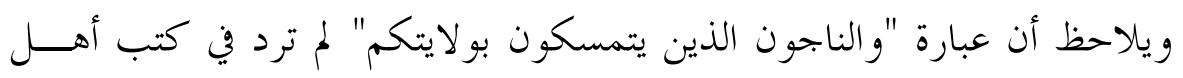

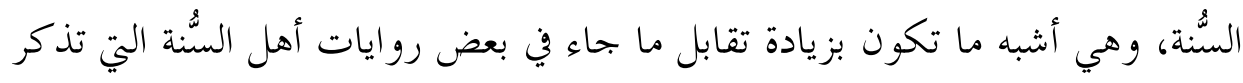
أن الفرقة الناجية هم "الجماعة".

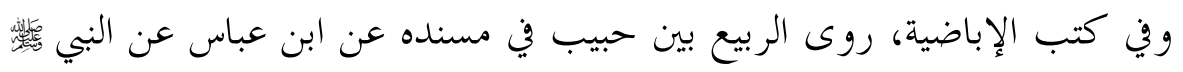

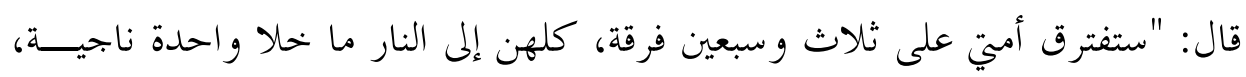

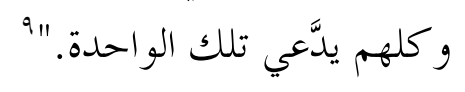

ويلاحظ أن عبارة "و كلهم يدعي تلك الو احدة" هي زيادة لا توجد في روايسـات

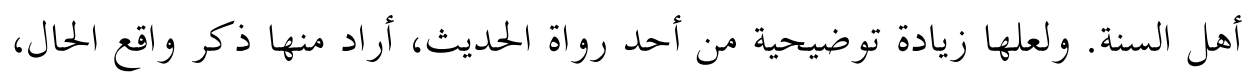

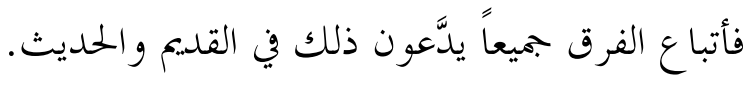

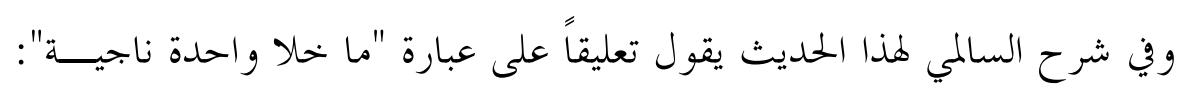

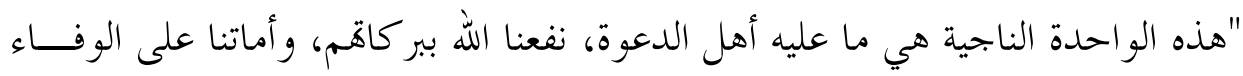

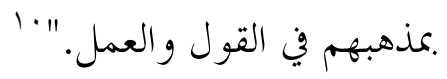

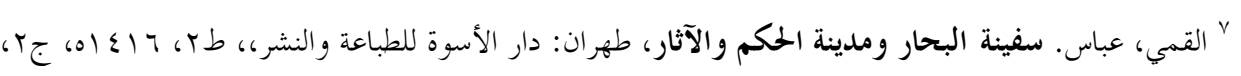

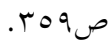

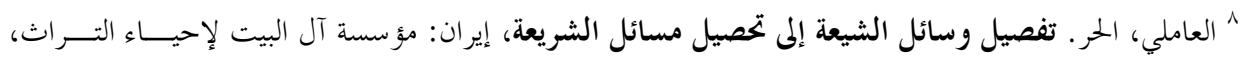

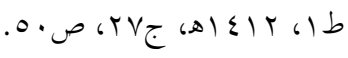

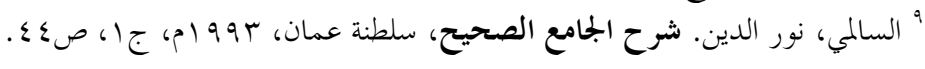




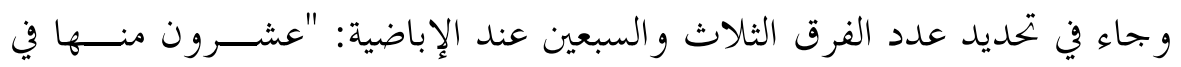

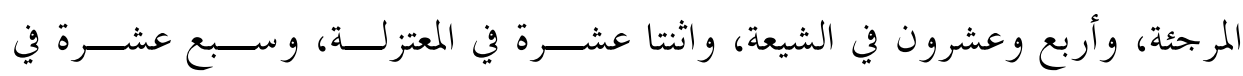
المخمة . المركة

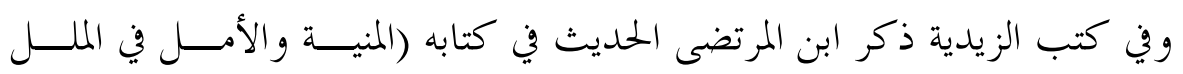

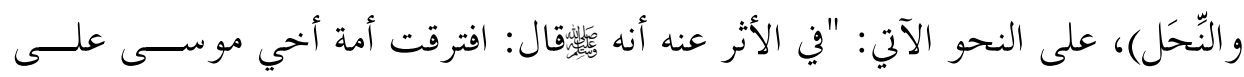

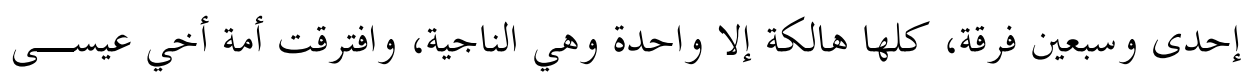

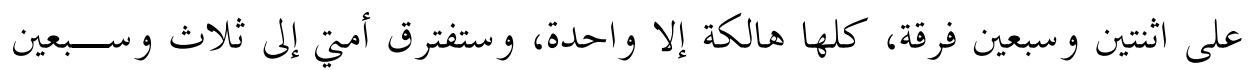

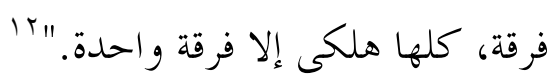

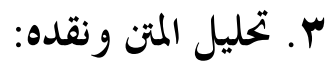

المتأمل في روايات حديث افتراق الأمة يمكن له أن يخرج بالملاحظات الآتية: أ. بعض الروايات اكتفت بذكر عدد الفرق دون الفرقة الناجية، مثل روايسـة أبي هر يرة.

ب. روايات ذكرت عدد الفرق، وذكرت الفرقة الناجية دون أن تحددها، مثـــلـ رواية أنس بن مالك. توابت دكرت

ت. روايات ذكرت صفات الفرقة الناجية، مثل رواية عبد الله بن عمر التي رواها

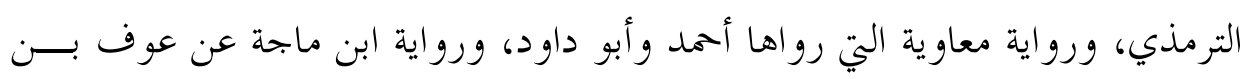

مالك.

ث. يلاحظ أن الرواية التي رواها معاوية قد أشارت إلى "الجماعــة". ومفهـــوم

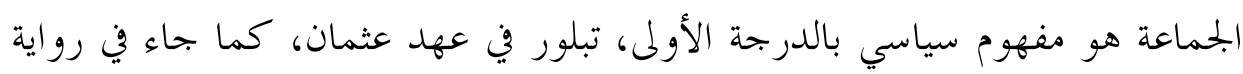

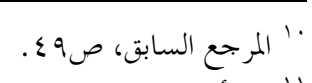

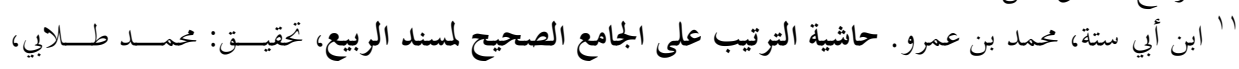

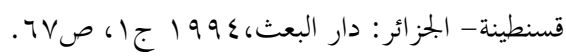

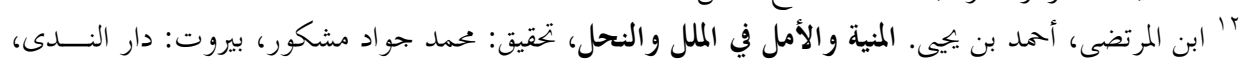

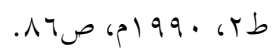




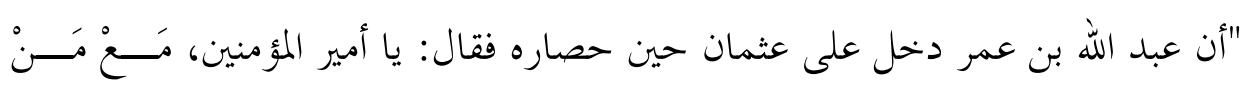
تأمرلي أن أكون إن غلب عليك هؤلاء؟ قال: عليك بلزوم الجماعة، قلت: فإن كانت

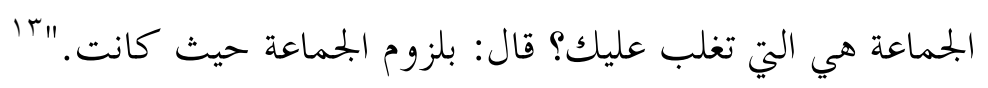

ج. لم يُخرِّج الإمام مالك و البخاري ومسلم و النسائي حديث الفرقـــة الناجيــة، وهذا يثير التساؤل عن سبب عدم روايتهم للحديث، ويدعم موقف من طعن في صحة

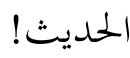

ح. ومن الروايات الغريبة لحديث اختلاف الأمة الرواية التي يوردها العجلوني في

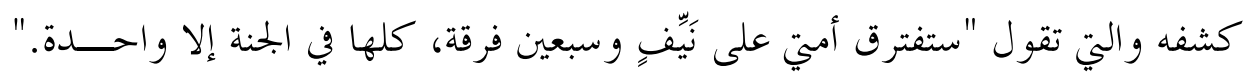

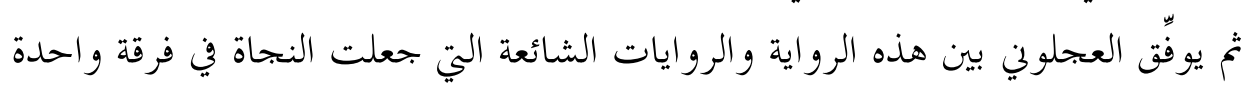

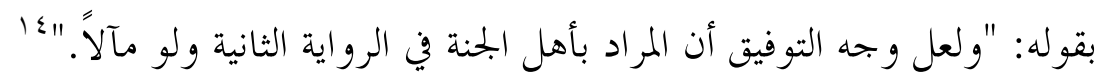
ولعل هذه الرواية (كلها في الجنة إلا واحدة) تؤ كد مدى اضطراب ألفاظ حديث

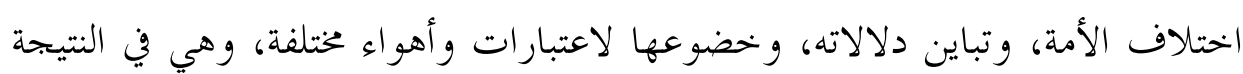
تدعم قول من طعن في الحديث وردّه.

ومن أبرز العلماء الذين رفضوا صحة حديث افتراق الأمة الإمام ابن حزم، الذي

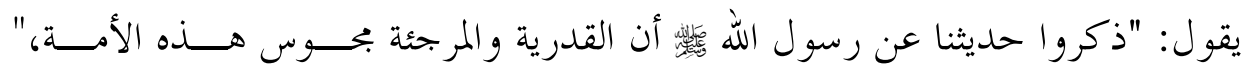

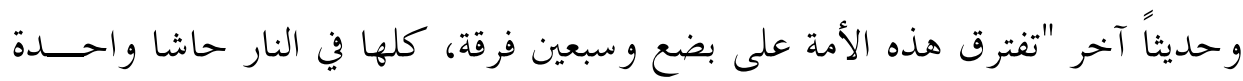

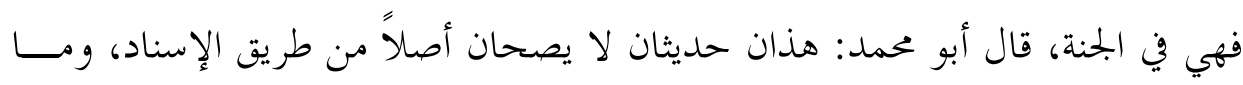

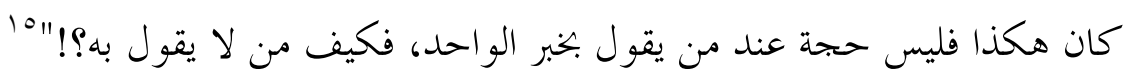

rا ابن قتيبة الدينوري، أبو محمد عبد الله. الإمامة والسياسة، تحقيق: طه محمد الزيني، القاهرة: مؤسســة الحلـبـي

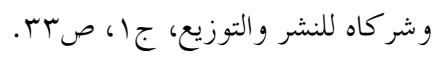

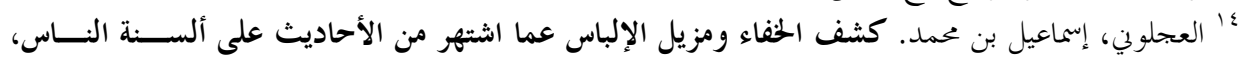

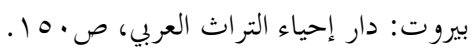

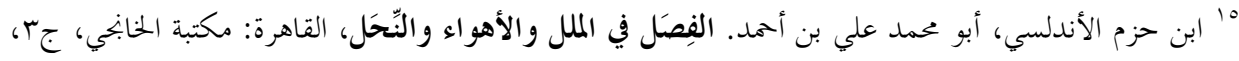




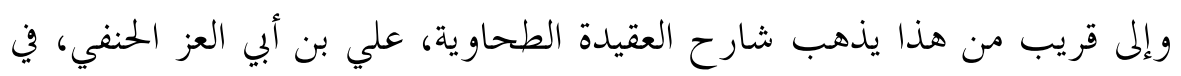

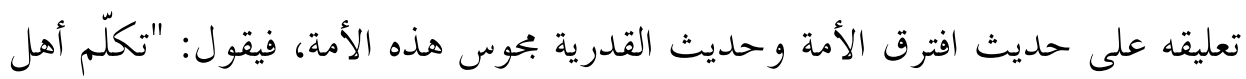

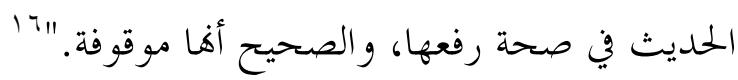

وقال محمد ابن الوزير: "إياك والاغترار بــ(كلها هالكة إلا واحدة)، فإنها زيــادة

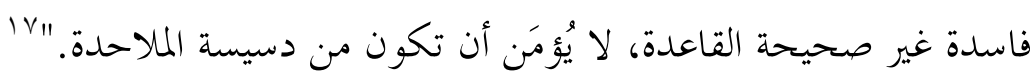

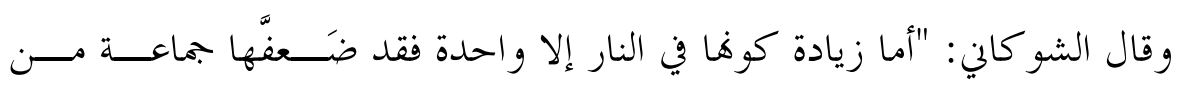

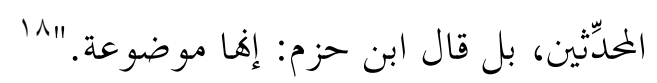

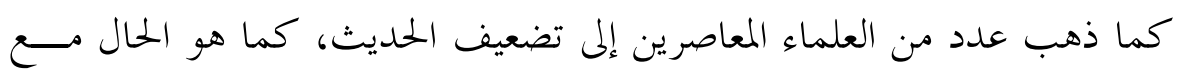
الشيخ القرضاوي الذي استدل بتضعيف ابن حزم و نقد ابن الوزير للحديث. 19 وهناك من ذهب إلى أن الحمديث هو رواية مختلقة وموضوعة: "الحديث قد وضعته

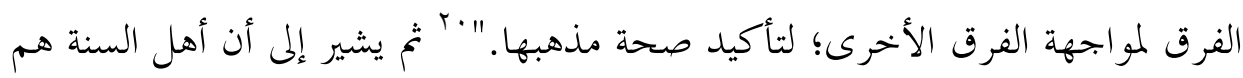

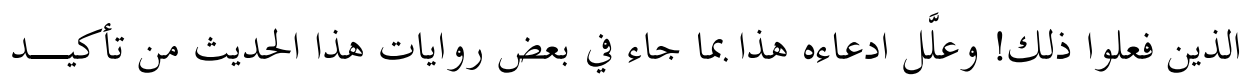

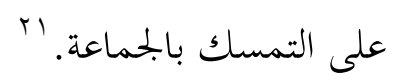

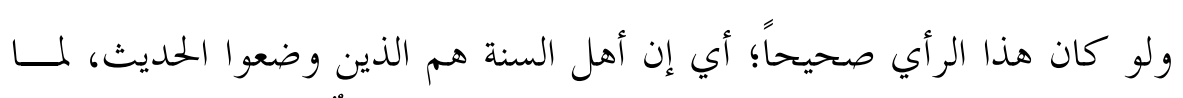

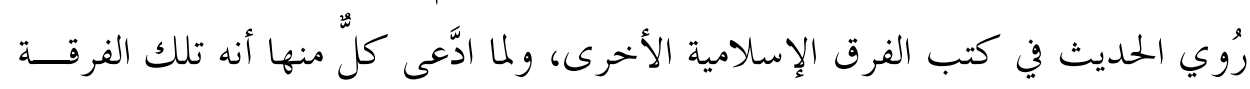

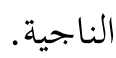

"1 ابن أبي العز الحنفي، علي بن علاء الدين. شرح العقيدة الطحاوية، بيروت،المكتب الإسلامي، اجrاهـ، طع،

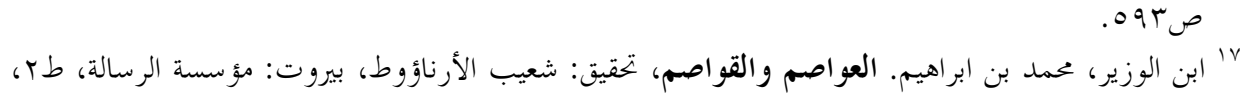

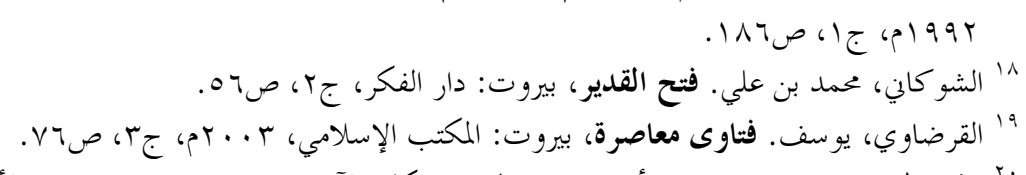

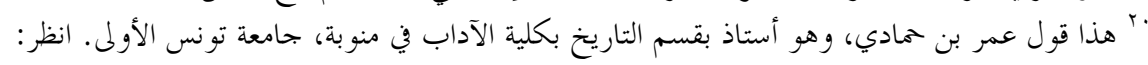

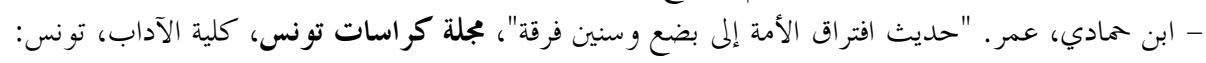

$$
\text { r"r المرجع السابق. }
$$


و يضاف إلى أوجه النقد السابقة بخصوص حديث افتراق الأمة النقاط الآتية:

- أنه يبجعل الفُرقة بين المسلمين كأها قدر محتوم لا منجى منها ولا مهرب، وأنسـه

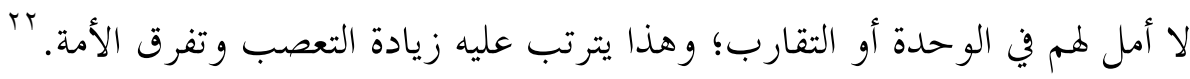

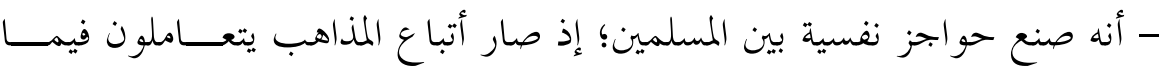
بينهم كأفم ديانات مختلفة.

- جعل للفرق شرعية في تضليل بعضهم بعضاً، وأدى إلى هدر طاقات كــثيرة في سبيل تشويه مخالفيهم. - أنه يعكس التوظيف السياسي، و يعطي تسويغاً شرعياً لقمع الخصوم و الخارجين عن الجماعة (السلطة).

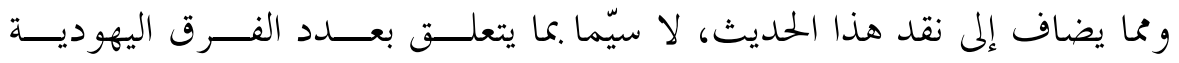
و النصرانية، أن العديد من الفرق الجديدة قد ظهرت في الديانتين اليهودية والمســيحية

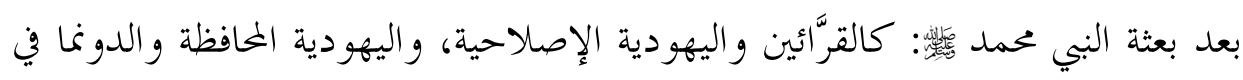
اليهودية، و البروتستانت و المورمون وغيرهم في المسيحية.

إن المضمون الجوهري لحديث افتراق الأمة (على افتراض صحته)، يجب أن يتمثل في التأكيد على الوحدة و التحذير من الافتراق والانحراف عن تعاليم الدين، وفي الحث على دراسة أسباب الاختلاف وفهمها على قاعدة السنن الاجتماعية، التي تظهـــر أن

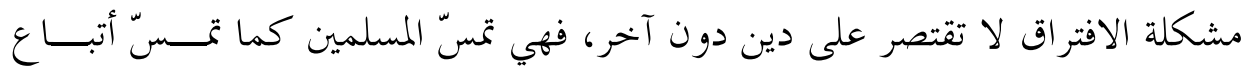
اليهودية و المسيحية وغيرهم من أتباع الأديان و النّحل على مرّ التاريخ.

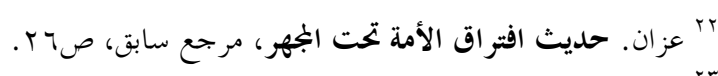

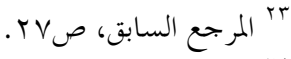

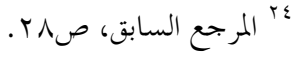

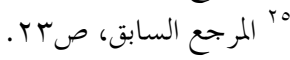




\section{ثانياً: المقصود بالأمة في حديث اختلاف الأمة}

اختلف العلماء حول المقصود بالأمة في حديث الافتراق، فذهب بعضهم إلى أهـــــا

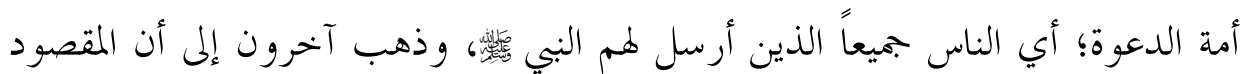

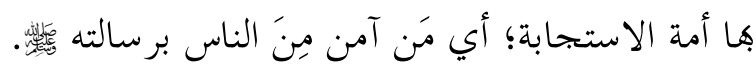

\section{القول الأول: إن المقصود بالأمة هو أمة الدعوة}

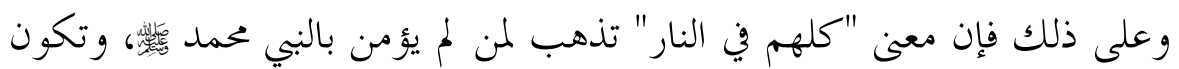

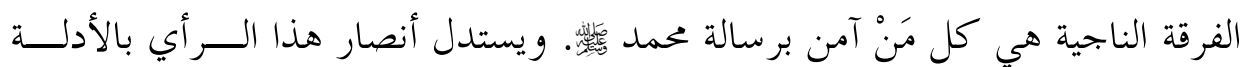
الآتية:

1. الأصل في استعمال كلمة الأمة هو العموم، و لا يصرف اللفظ إلى الخصــوص إلا بدليل.

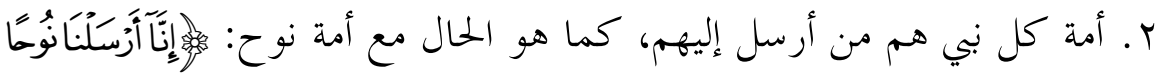

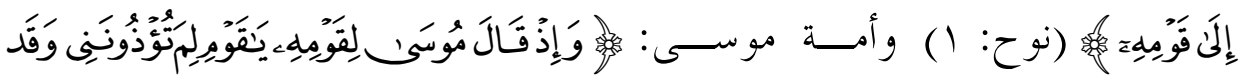

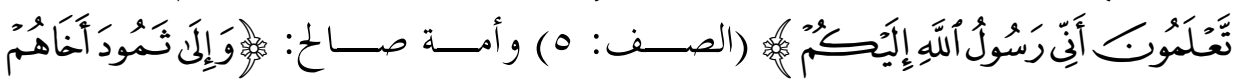

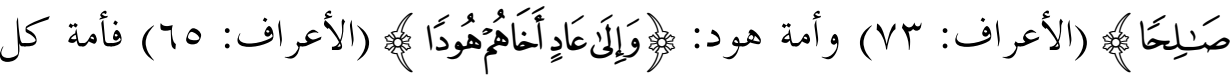
نبي هم القوم الذين أرسل إليهم، و البني محمدئس

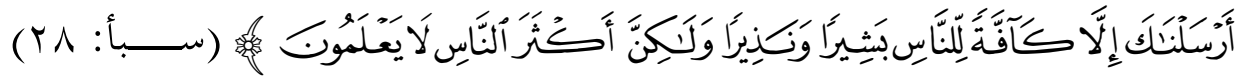

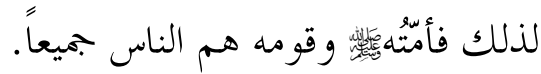

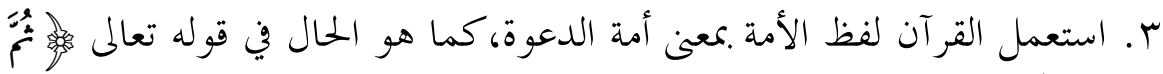

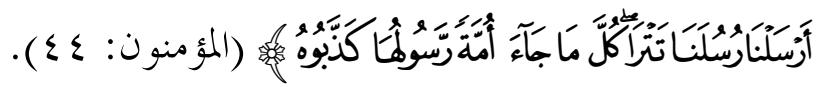
و يعترض على هذا القول بأنه لو كان المقصود بالأمة في الحديث هو أمة الــدعوة

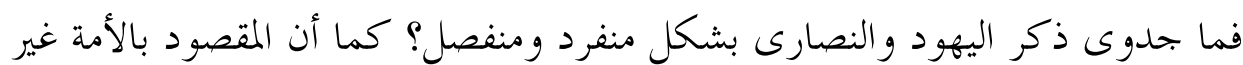




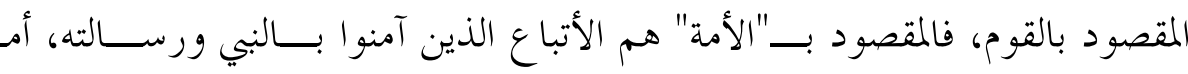

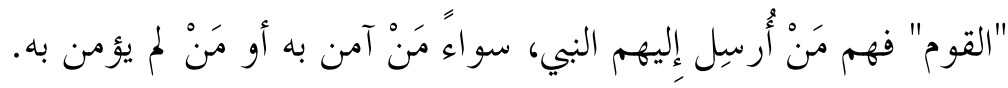

\section{القول الثاني: أن المقصود بالأمة أمة الإجابة}

يذهب الصنعاني إلى أن المقصود بالأمة في حديث افتراق الأمة هو أمة الإجابــة لا

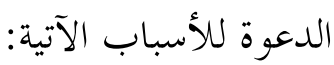

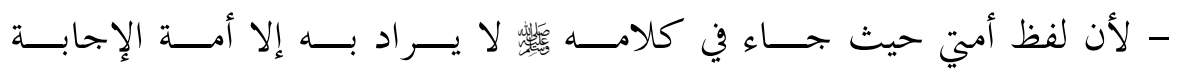

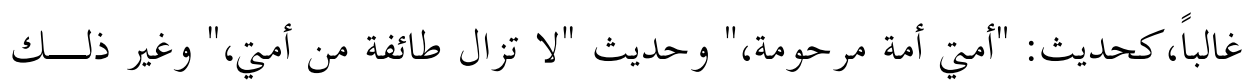

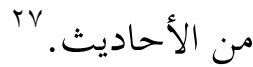

- قوله "ستفترق" بالسين الدالة على أن ذلك أمر مستقبل، ^^و ويقصد الصــنعاني

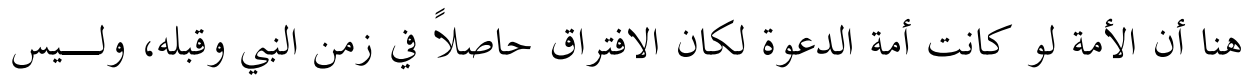
بعده.

- أنه قرفم بطائفتي اليهود والنصارى؛ و كون المفترقين منهما هما طائفتا الإجابــة

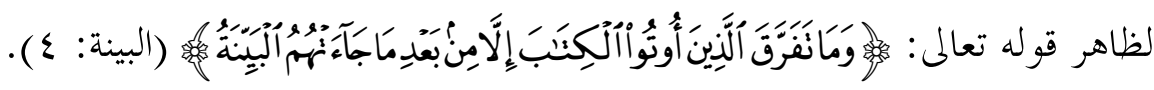

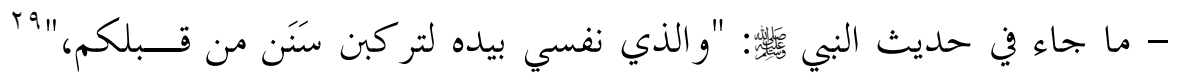
وهذا خطاب لأمة الإجابة قطعاً.

ويستدل أنصار هذا الرأي، وهم جمهور العلماء، بأن هذا هو ظاهر استعمال لفظة

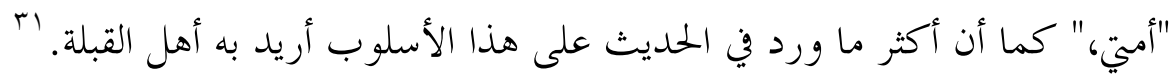

دv الصنعاني، عمدد بن إسماعيل. افتراق الأمة إلى نيف وسبعين فرقة، تحقيق: سعد بن عبد الله السعدان، الرياض:

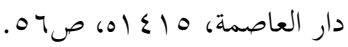

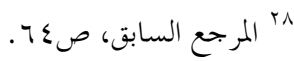

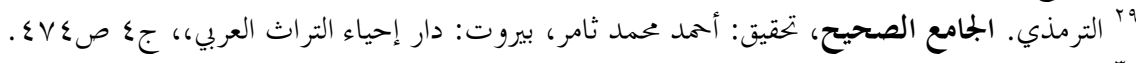

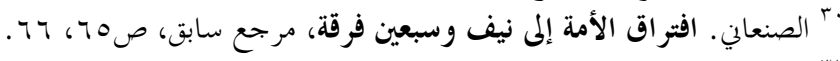

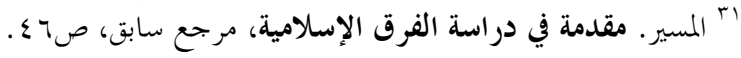


أمة الاستجابة هي أمة الوحدة لا أمة الفرقة، وعلى ذلك فبإن مَنْ زعــــم الإيمـــان

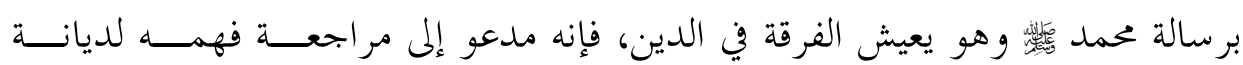
التو حيد.

\section{ثالثاً: عدد الفرقة ودلالاته في الحديث}

اختلف العلماء في مفهوم العدد في حديث افتراق الأمة إلى قولين:

\section{القول الأول: أن المقصود به كثرة طرق الهلاك}

ذهب عدد من العلماء الى أن المقصود بالعدد المذكور في حديث افتراق الأمة هو

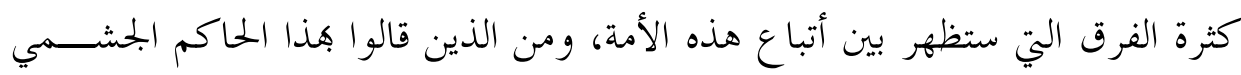
الذي ذهب إلى أن المراد بالعدد ليس الحصر، وإنما المراد ستفترق أميت فرقــاً كــثيرة،

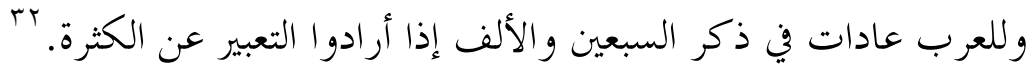

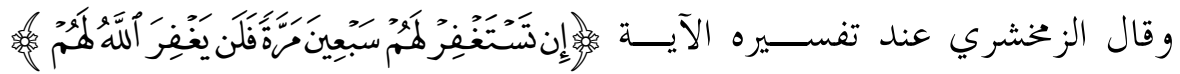

$$
\text { (التوبة: • 1)): "والذي يفهم من ذكر هذا العدد كثرة الاستغفار.."r }
$$

و جاء في شرح النووي لصحيح مسلم في سياق شرحه لحلديث "الإيمـــان بضـــع و سبعون شعبة": ذكر ابن أبي حاتم أن رواية من روى "بضع و سبعون شـــعبة" أيضــــا صحيحة، فإن العرب قد تذكر للشيء عدداً و لا تريد نفي ما سواه. عَ وذهب الصنعاني إلى أن المقصود بالعدد ليس ذات العدد أو كثرة الهالكين: "ليس

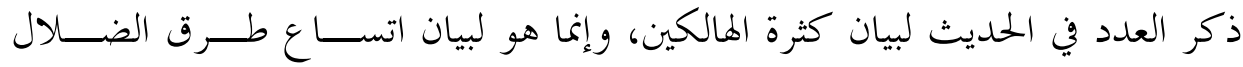

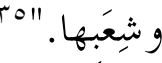

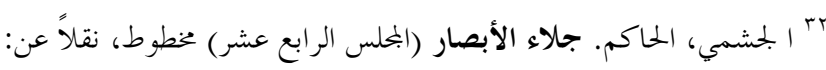

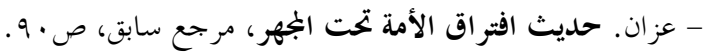

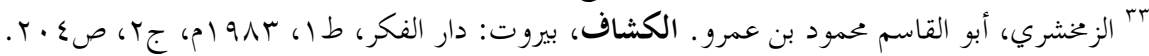

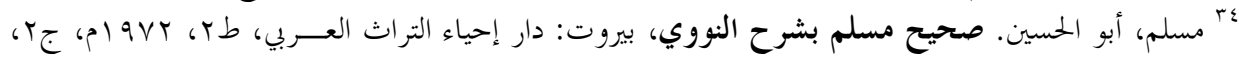




\section{القول الثاني: أن العدد مقصود بذاته}

اختلفَ أنصار هذا القول في تسويغ تباين عدد الفرق في الو اقع مع العدد الوارد في العي

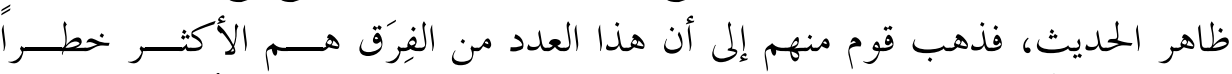

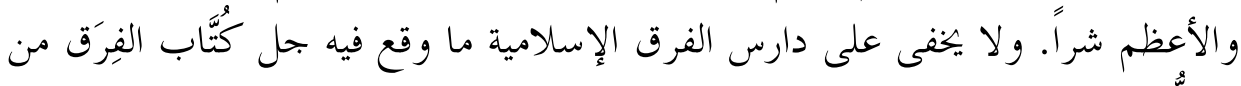

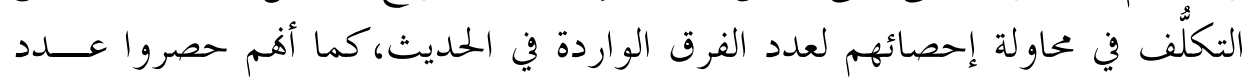

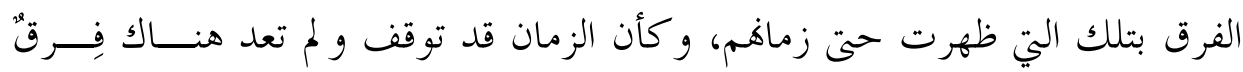

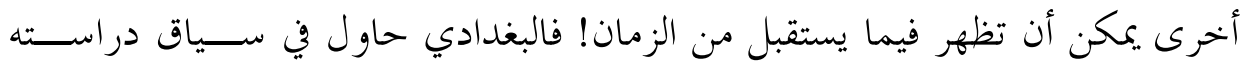

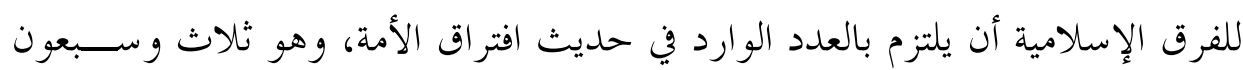

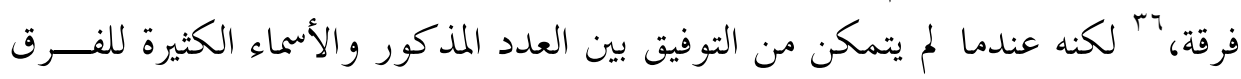

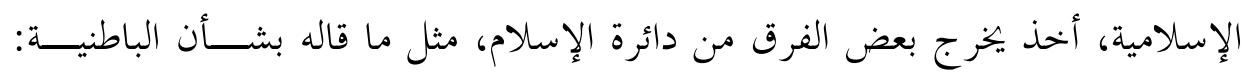

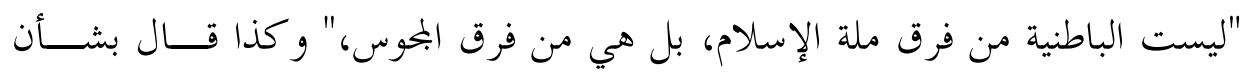

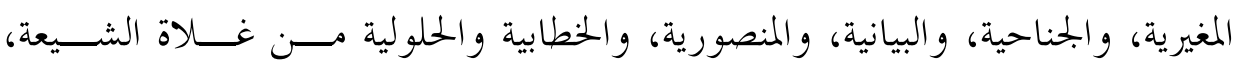

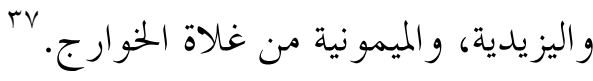

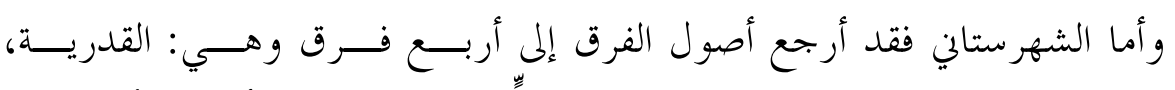

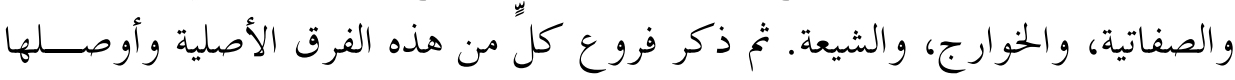

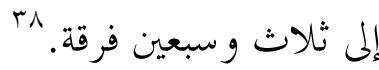

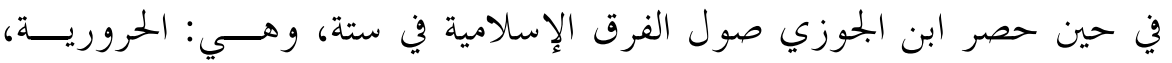

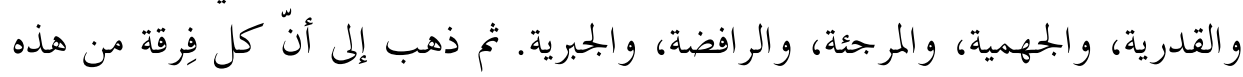

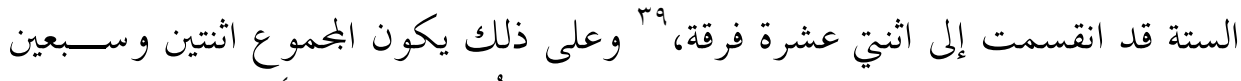

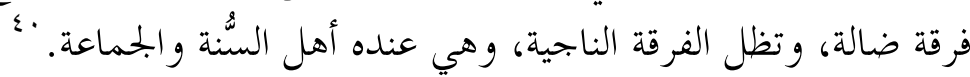

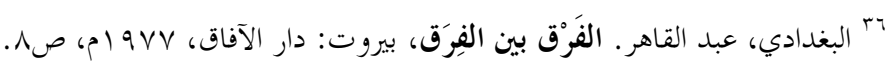

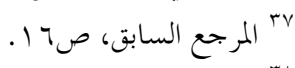

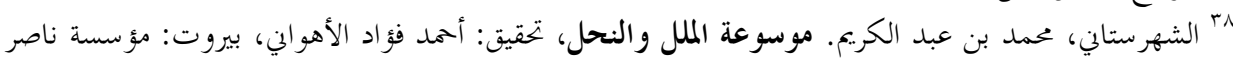

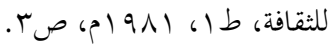

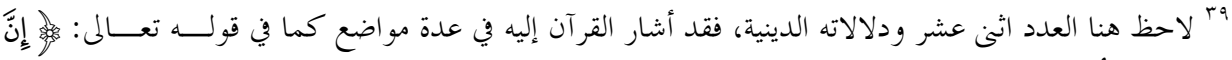

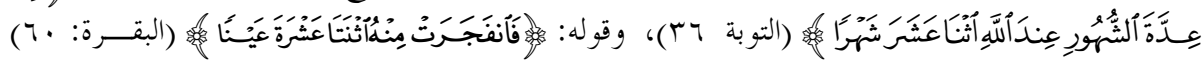

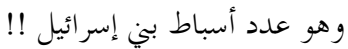

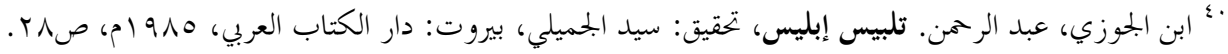




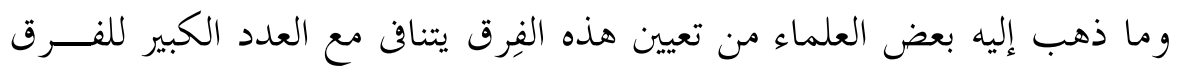

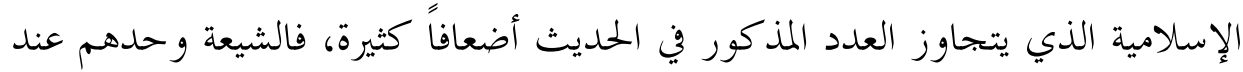

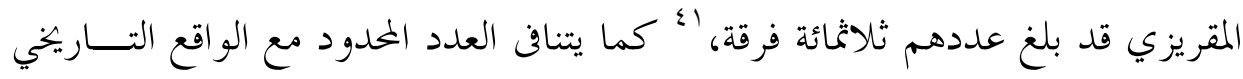

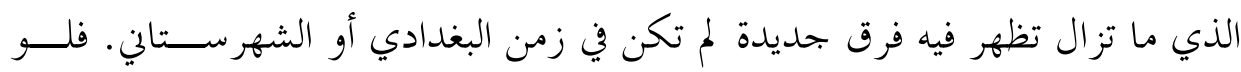

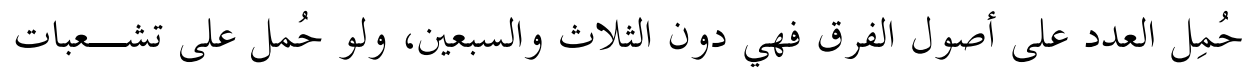
تلك الفرق وفروعها لتجاوز ذلك العدد!

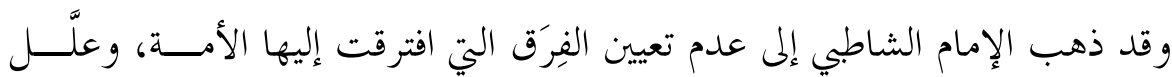

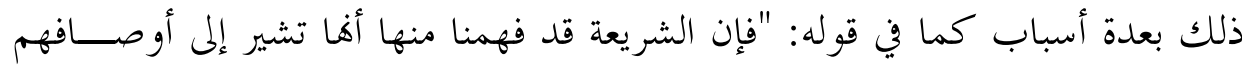

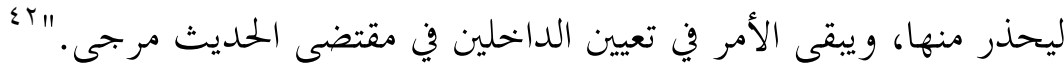

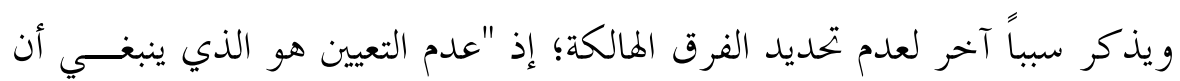

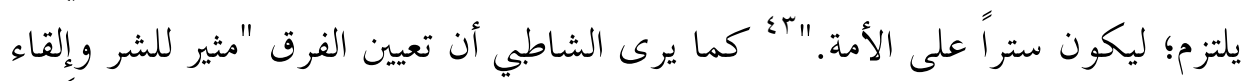

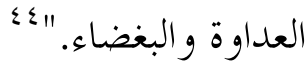

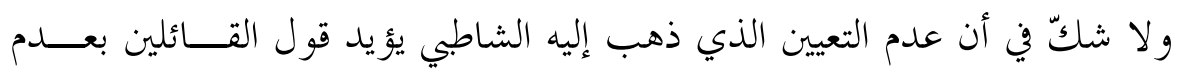

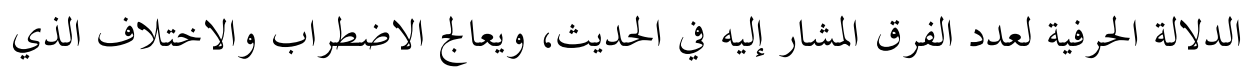
وقع بين كتّاب الفِرَق في تحديد هو لفية هذه الفِرَق.

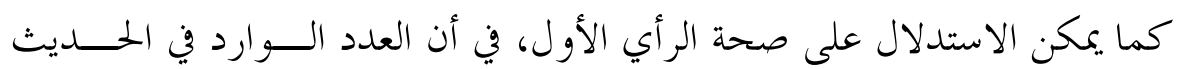

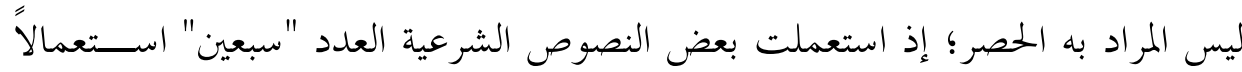

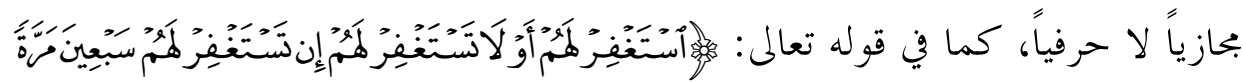

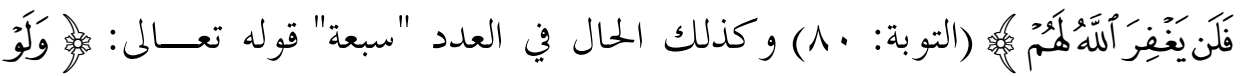

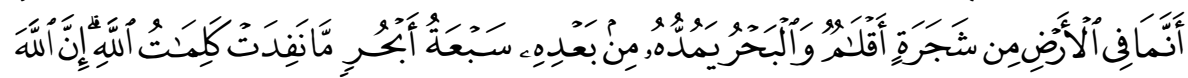

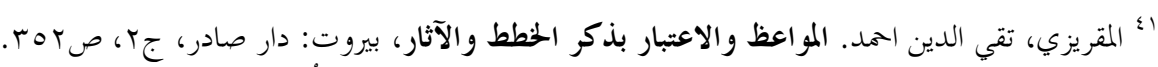

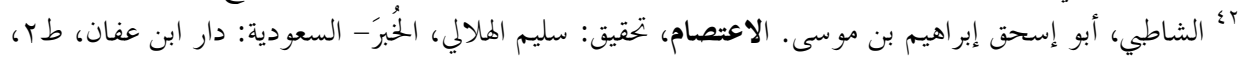




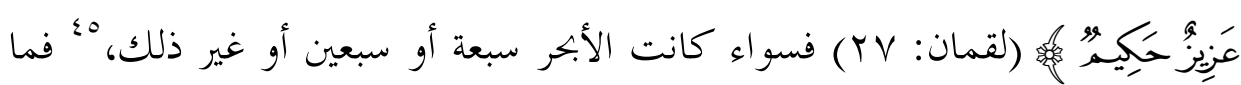
كان لكملمات الله أن تنفد.

\section{رابعاً: المقصود بقوله (كلها في النار)}

يذهب بعض الباحثين إلى أن عبارة (كلها في النار) لا تستلزم كفر تلك الفـــــ؛

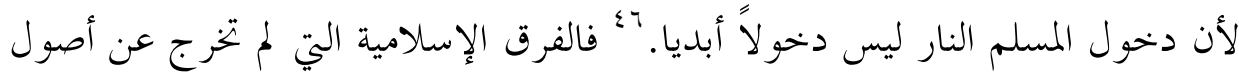

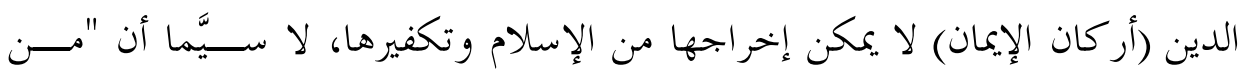

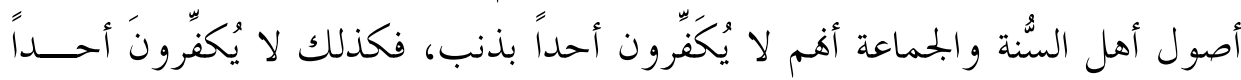
ببلدعة.

يقول الإمام الصنعاني في شرح حلديث افتراق الأمة: "إنّ الحلديث استشكل مــن

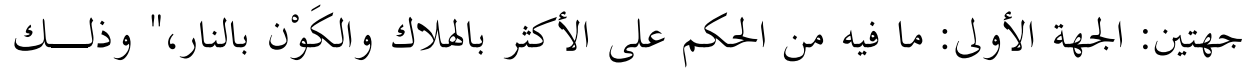

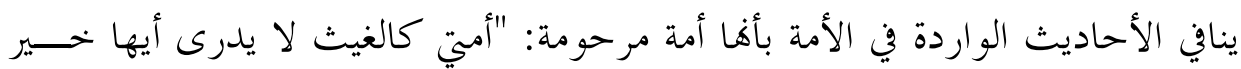

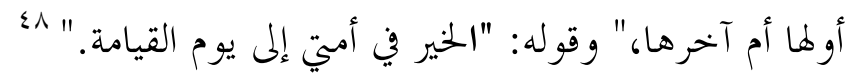

و يضاف إلى ما ذكره الصنعاني ما رو اه مسلم عن عبد الله، قال: "قال لنا رســـول

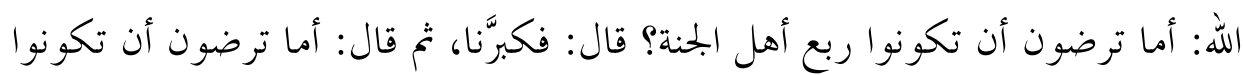

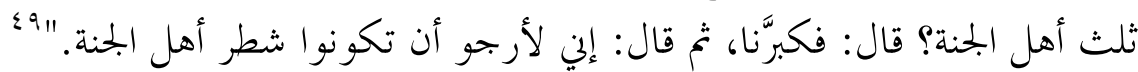

فكيف يرجو البي أن تكون أمته نصف أهل الجلنة إذا لم تنجُ من أمتــهـه إلا فرقــة

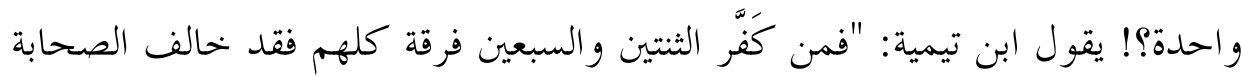

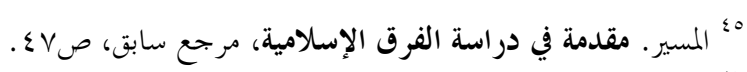

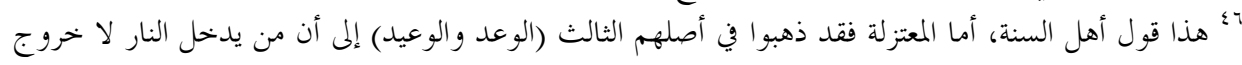
له منها. انظر:

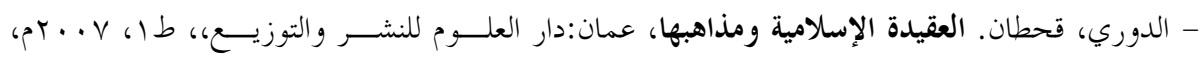

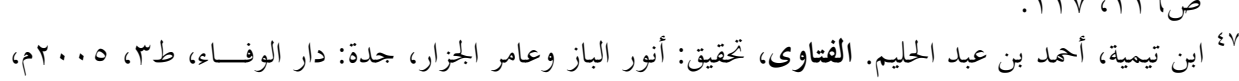

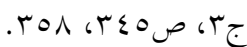

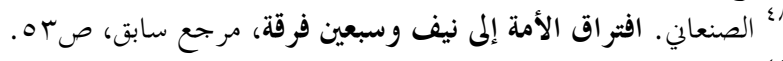

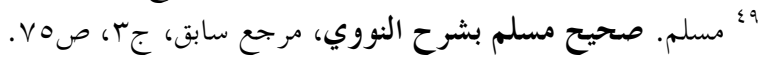




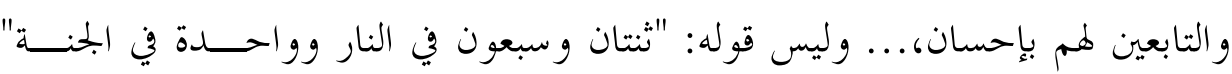

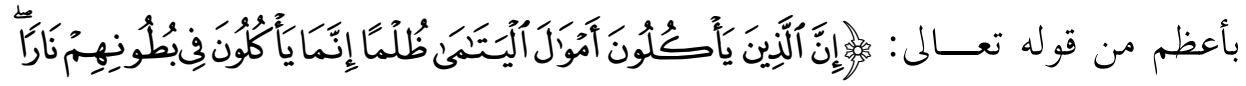

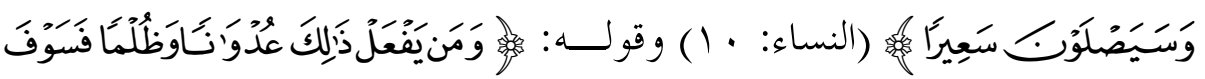

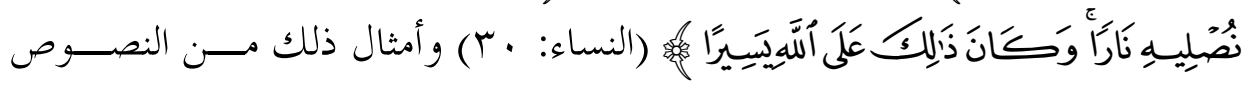

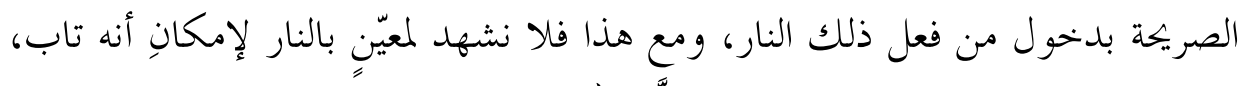

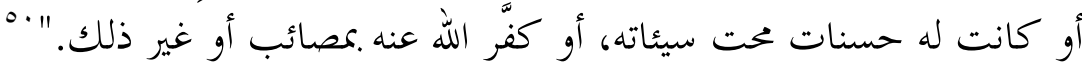

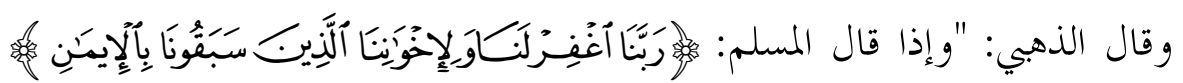

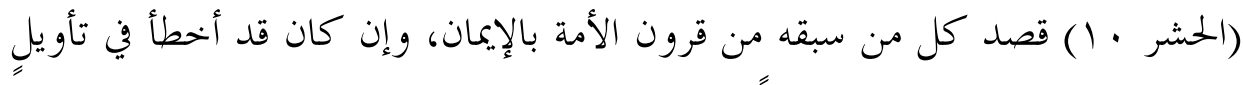

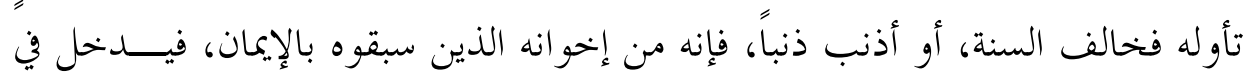

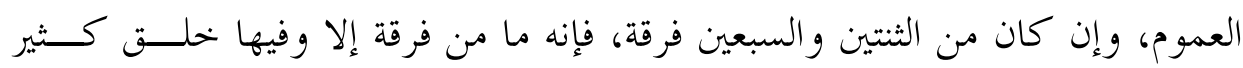

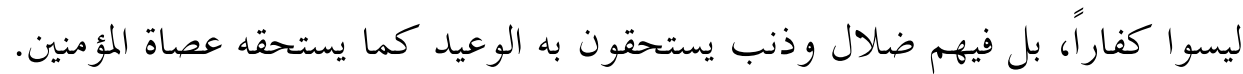

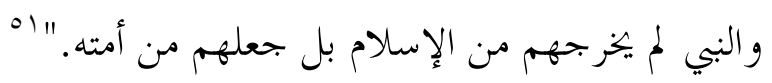

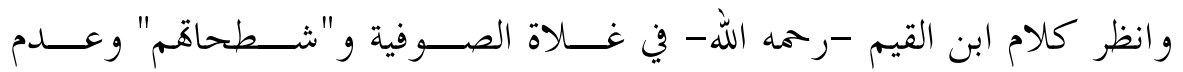

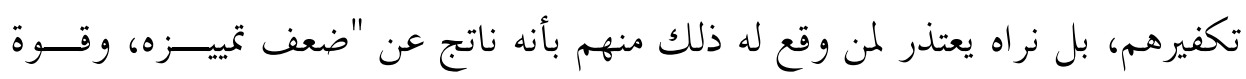

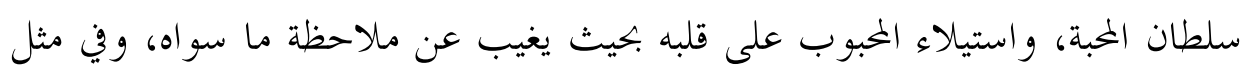

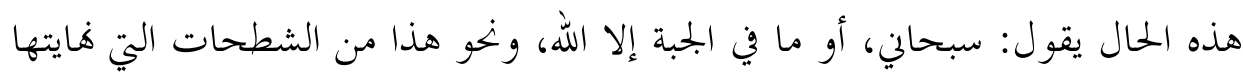

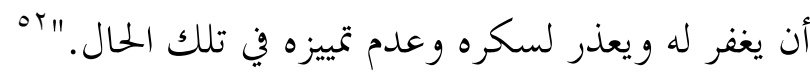

كما ينبغي أن لا نحكم على أتباع كل فرقة من فرق المسلمين بحكم واحد: فمنهم

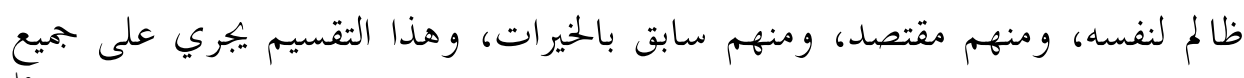

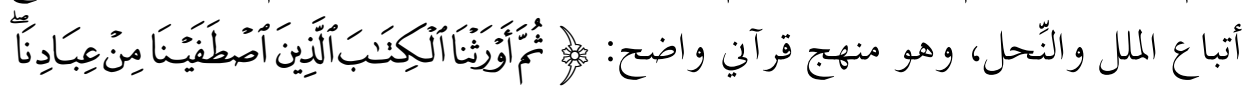

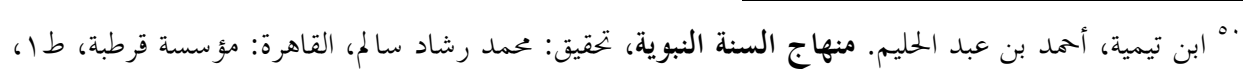

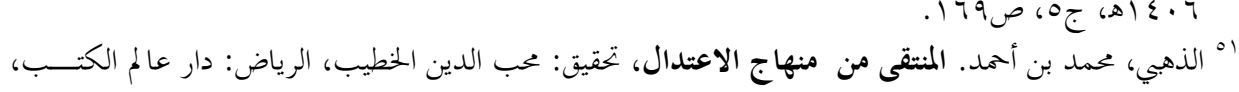

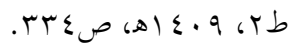

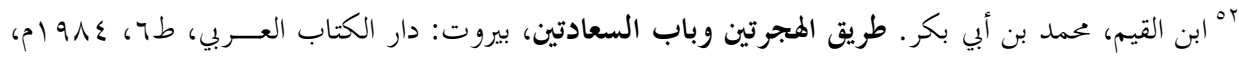




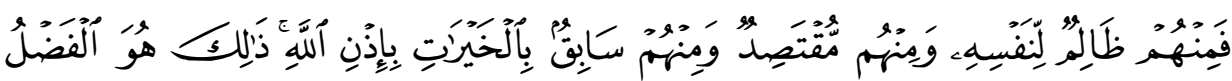

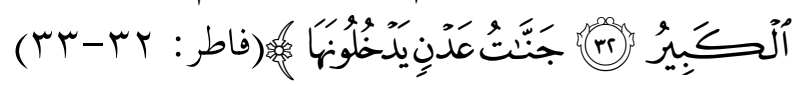

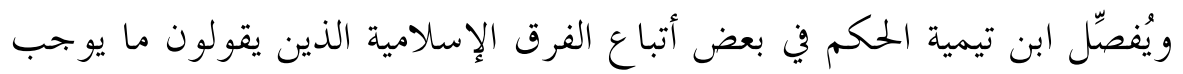

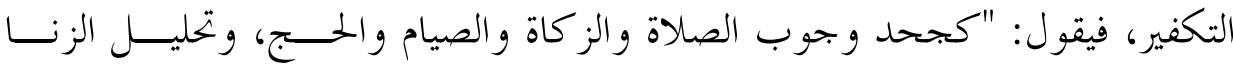

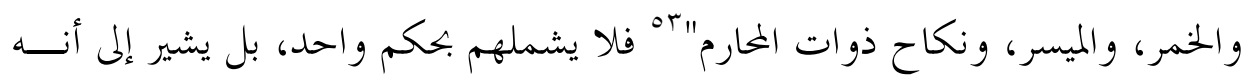

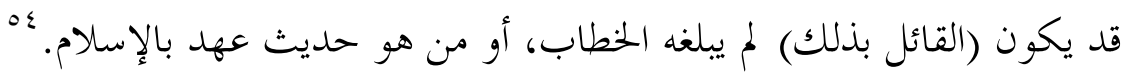

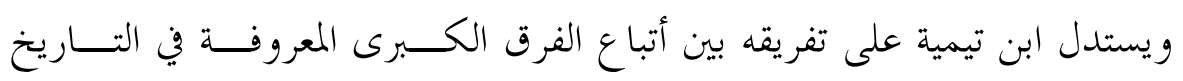

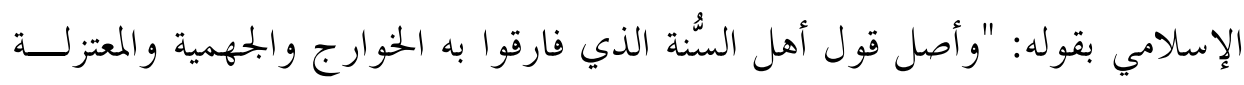

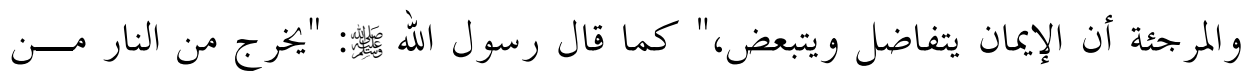

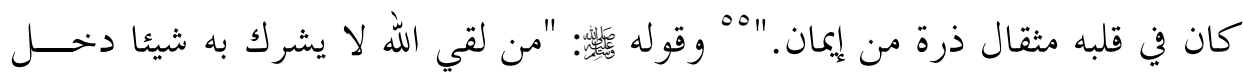

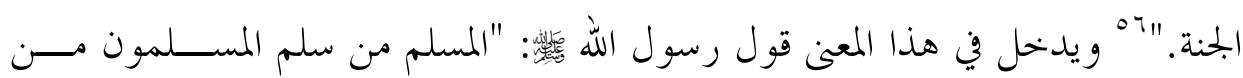

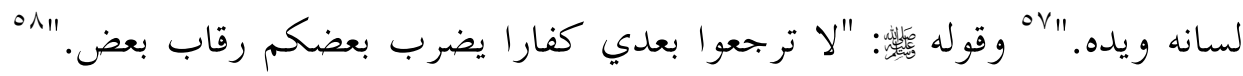

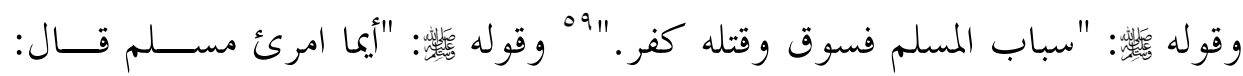

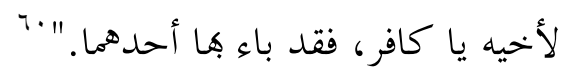

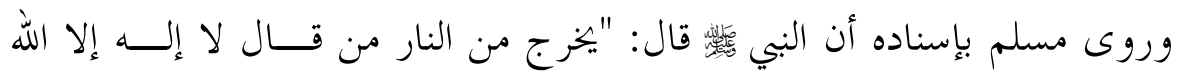

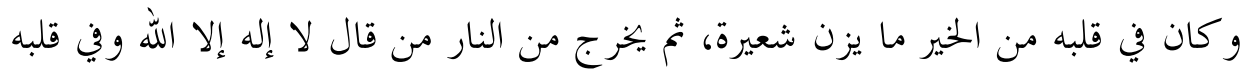

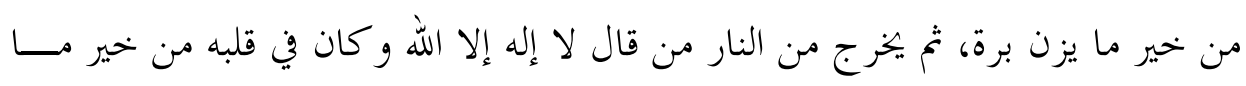

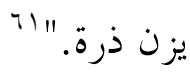

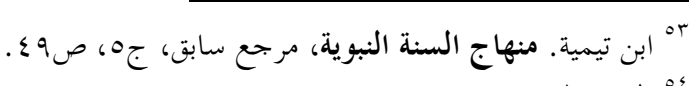

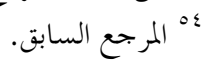

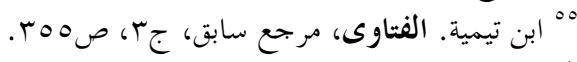

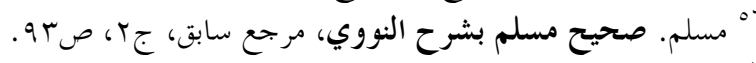

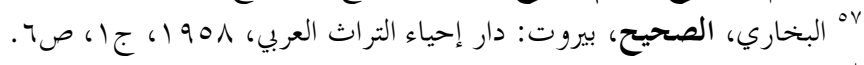

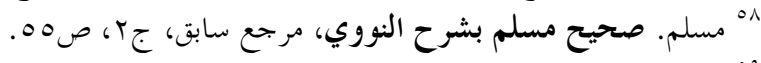

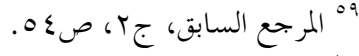

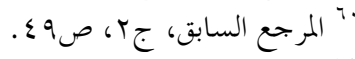

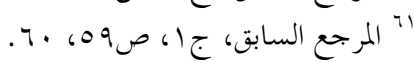




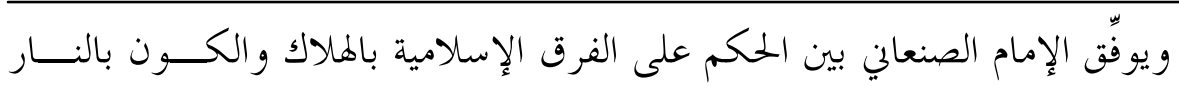

و كوفنا أمة مرحومة بقوله: "الحلكم على تلك الفرق بالهلاك و الكون في النار، حككــم عليها باعتبار ظاهر أعمالها، ولا ينافي ذلك كوفا مرحومة باعتبار آخر، من رحمــــة الله

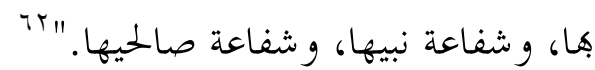
ولذلك ينبغي التغريت بين نوعين من الهلاك:

- - الملاك المطلق: وهو الذي لا رجاء لصاحبه بالخرو ج من العذاب يوم القيامة. - المالك المؤقت: وهو الذي يعذب صاحبه إلى أجل معلوم، ثم يدخلـــه الله في رحته و وحنته.

من هنا فبإن معظم أتباع الفرق الإسلامية تنالهم النجاة بالمآل بعـــد أن يســـتوفوا حسابكم عند الله.

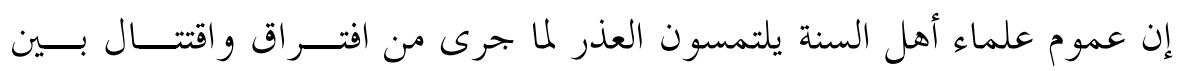
الصحابة، و لا يقولون بكفر أحد منهم، و بناء على ذلك فإنه من باب أولى أن لا نكفّر من أساء إلى بعضهم لاعتقاده .كخالفته الحق، فليس من طلب الحت فأخطأه كمن طلب الباطل فأصابه.

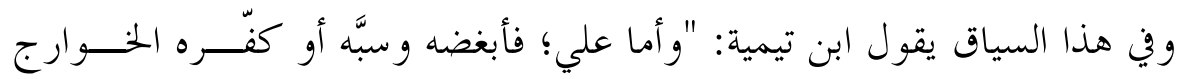
و كثير من بني أمية وشيعتهم الذين قاتلوه و سبّوه. فالخوارج تكفر عثمان وعلياً و سائر أهل الجماعة. و أما شيعة علي الذين شايعوه بعد التحكيم، وشيعة معاوية التي شـــايعته بعد التحكيم؛ فكان بينهما من التقاتل، و تلاعن بعضهم و تكافر بعضهم ما كان. "זr و هناك من يذهب إلى التفريق بين تكفير عوام أتباع الفـــرق الأخهـــى وتكفــير

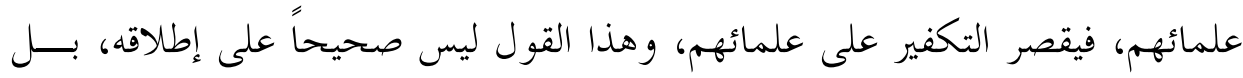
يُعترَض عليه من و جوه، أهمها: 


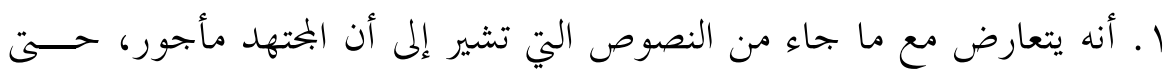

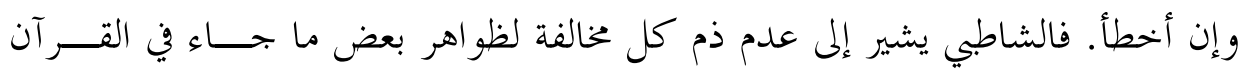

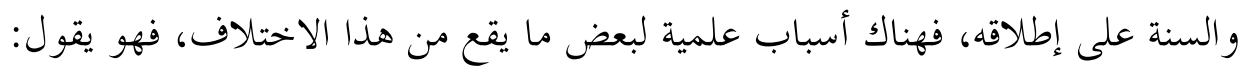

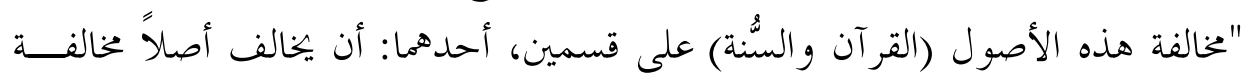

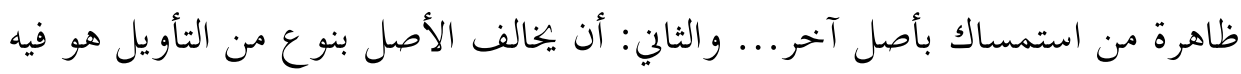
خغطئ."

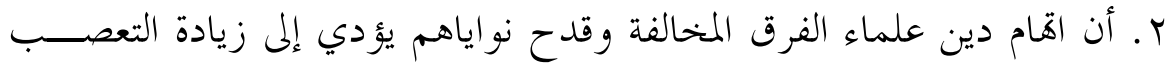

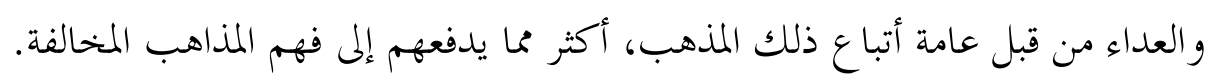

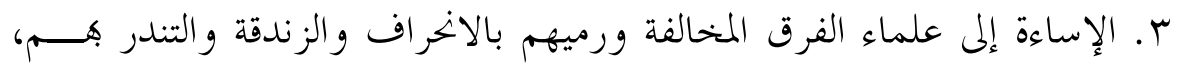

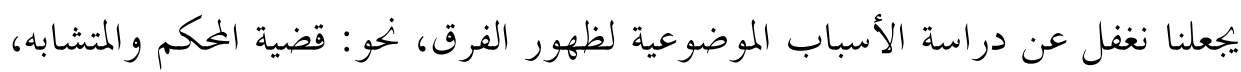

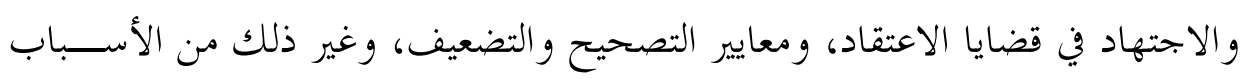
الداخلية للاختلاف.

\section{خامساً: المقصود بالفرقة الناجية}

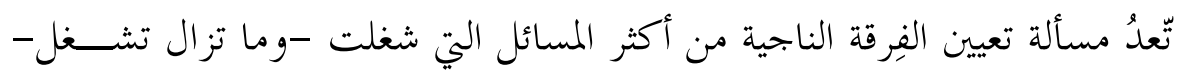

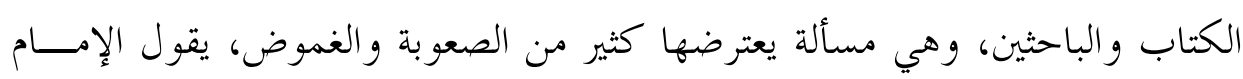

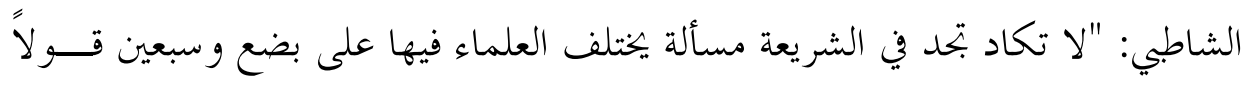

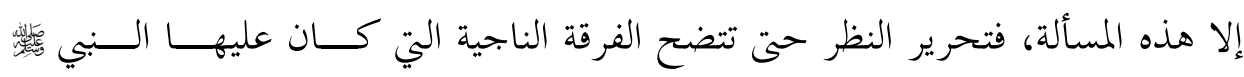
وأصحابه من أغمض المسائل."

كما أنه ما من فرقة من الفِرَق التي ظهرت في تاريخ الإسلام إلا وتدَّعي أها هي الته

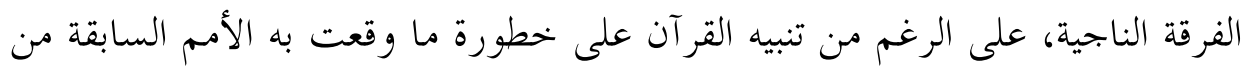

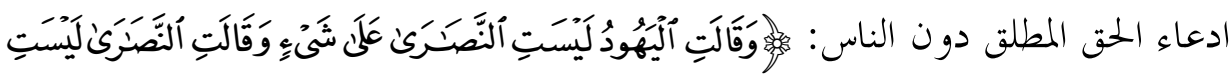

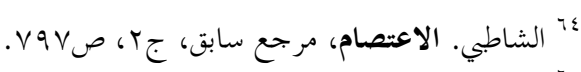

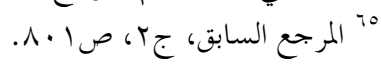




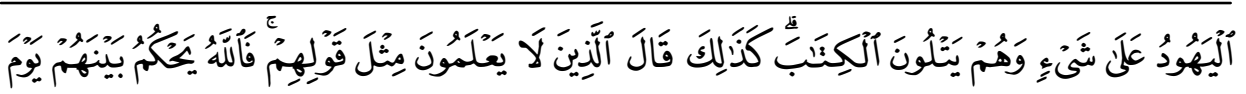

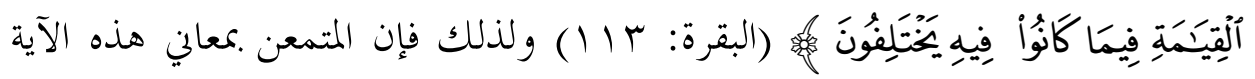
يدرك أن كل من اقتصرت معرفته على ادعاء الحق و النجاة لذاتها ولنهاء ونفي إمكانية النجاة عن غيره، فقد وقع .ما وقع به أهل الكتاب مِنْ قَبْلُ.

\section{ا ـ تعيين اسم الفرقة الناجية:}

مسألة تعيين الفرقة الناجية من المسائل التي تحتمل الظن و الاجتهاد، حتى وإن ادعى أتباع كل فرقة أهم الناجون دون غيرهم: "التعيين للفرقة الناجية بالنسبة إليه اجتهادي

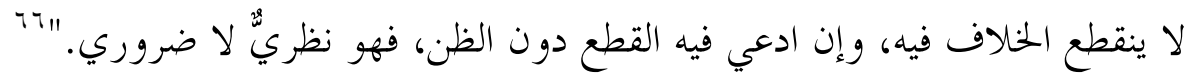
فالأمر الأولى بالنسبة لإمام الشاطبي -رحمه الله- في مسألة تعيين الفرقة الناجيـــة

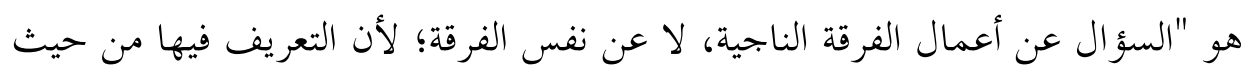

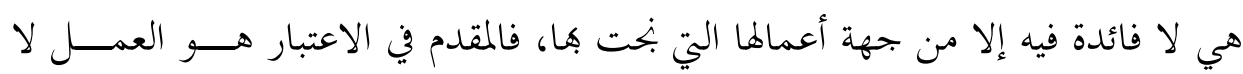
العامل."

و يستدل الشاطبي على أولوية السكوت عن تعيين النجاة بفرقة بعينها بحديث عمر

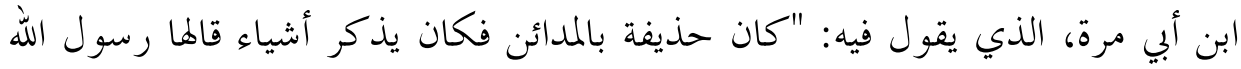

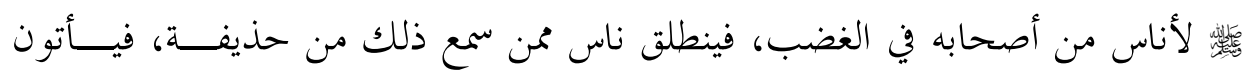

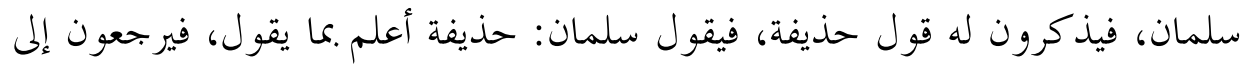

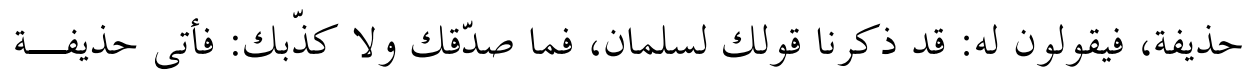
سلمان وهو في مبقلة فقال: يا سلمان، ما يمنعك أن تصدقين بما سمعت من رســـول الله لَّ

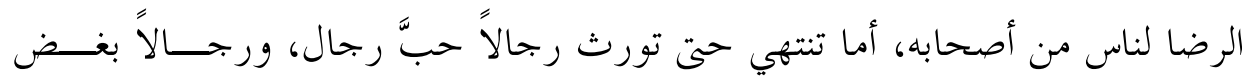

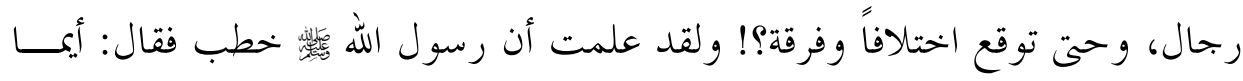

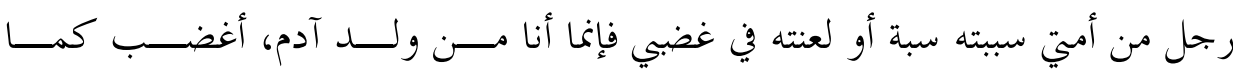

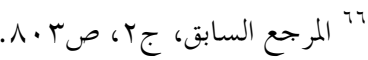

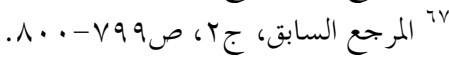


يغضبون، وإنما بعثني رحمة للعالمين فأجعلها عليهم صلاة يوم القيامة. فو الله لتنتهين أو ترائ

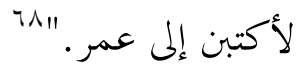

و وي هذا المعنى يقول ابن القيم في مدارج السالكين في حديثــهـ عــن علامـــات

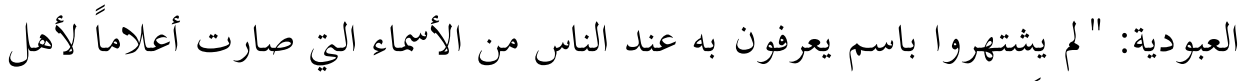

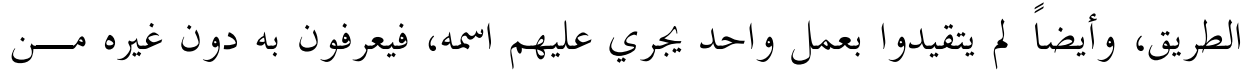

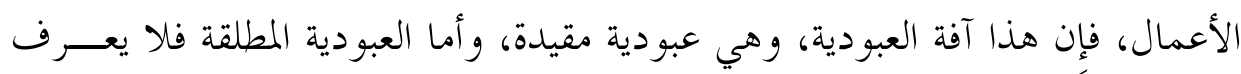

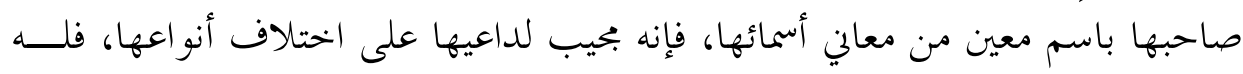

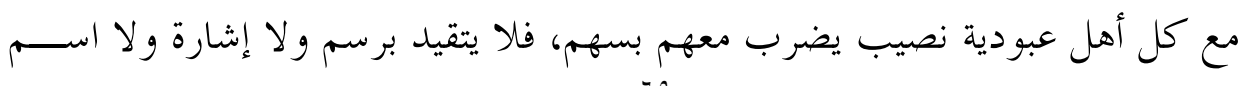

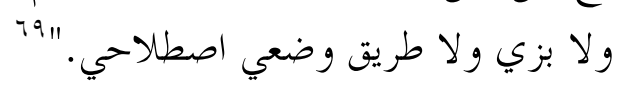

ومؤدى هذا الكلام أنه ينجو من كل فرقة من كان متمسكاً بحقيقة ما جاءه مـــن

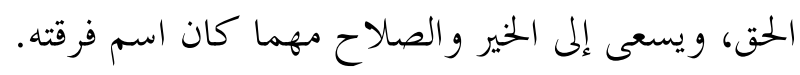

ويقول الإمام الصنعاني عن الفرقة الناجية: "وهم متبعو الرسول قولياً وفعلياً مــنـ

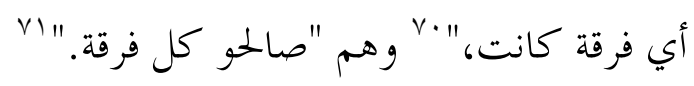

و انتقد الأفغاني الفهم الخاطئ الذي يجصر "الفرقة الناجية" في مذهب واحســــ دون سواه، وذهب إلى أن للنجاة جملة من الشرائط، وهي: الألوهية، والنبوة، و المعاد. وإذا لهاء

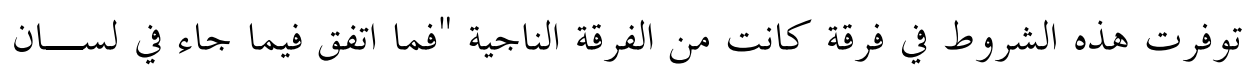

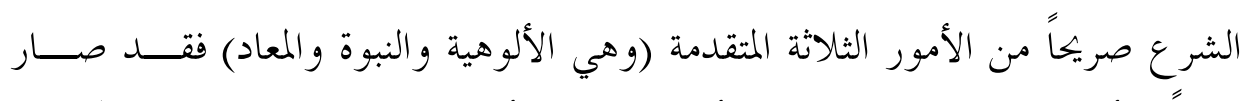

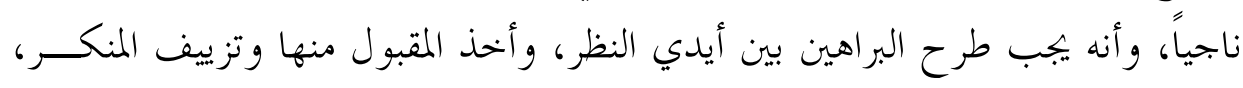

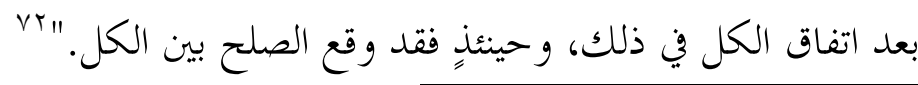

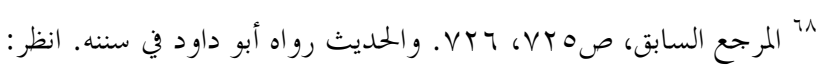

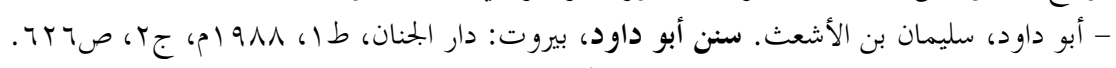

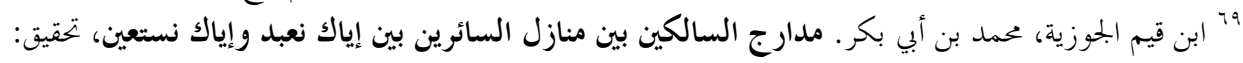

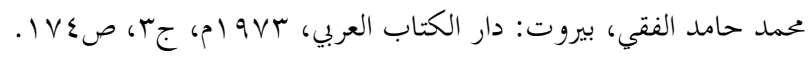

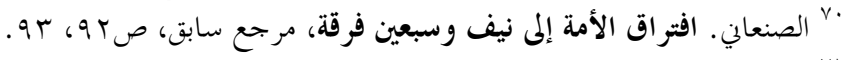

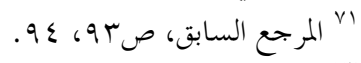

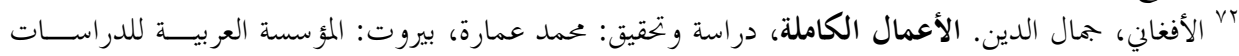

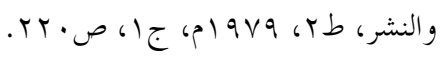




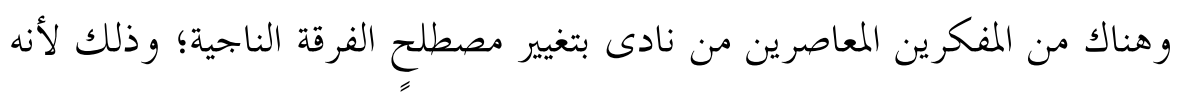

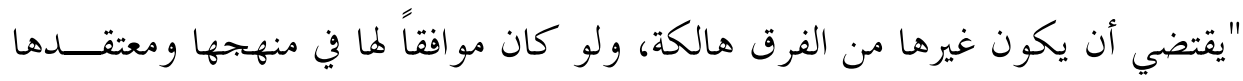

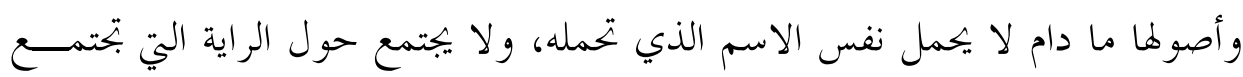

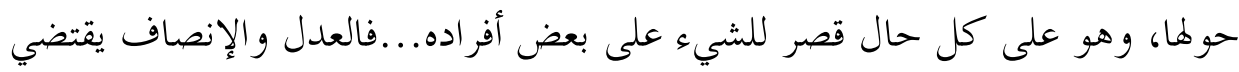

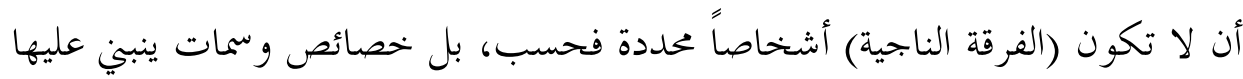

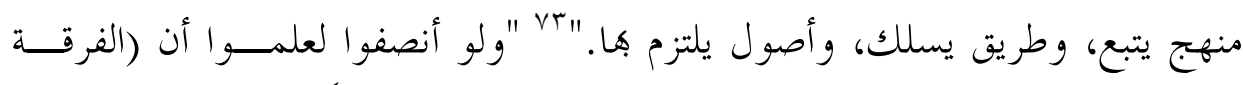

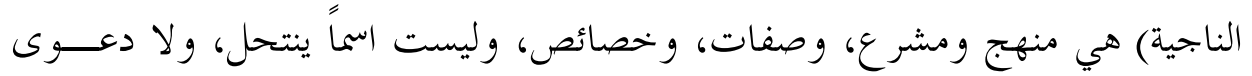

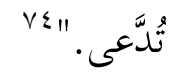

الفرقة الناجية هي مَنْ كان مِنَ المسلمين ملتزماً بالمضي على خط رسول الله، وأن النه

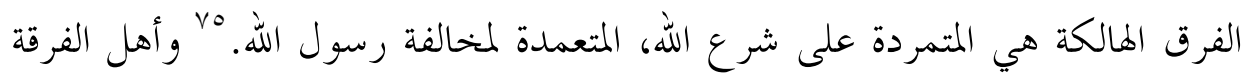

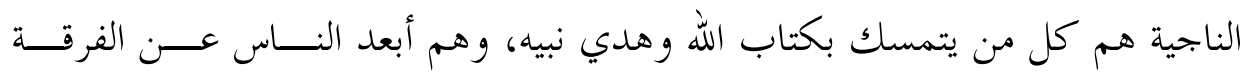

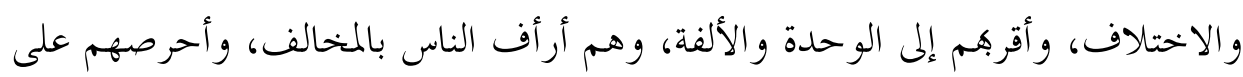

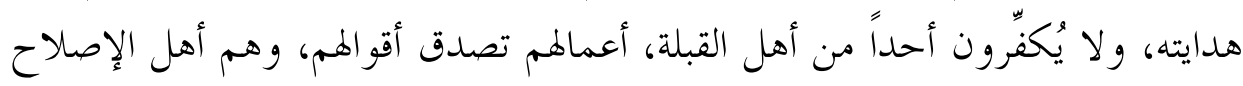

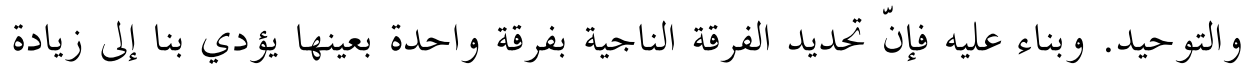

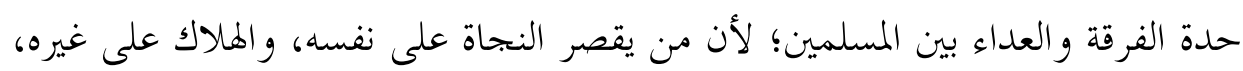

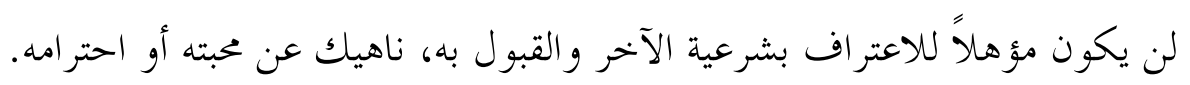

\section{Y r عموم النجاة لأمة محمد}

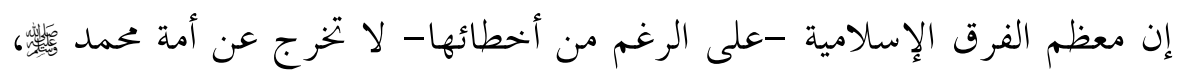

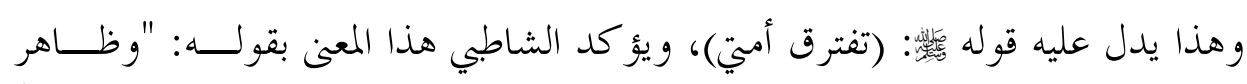

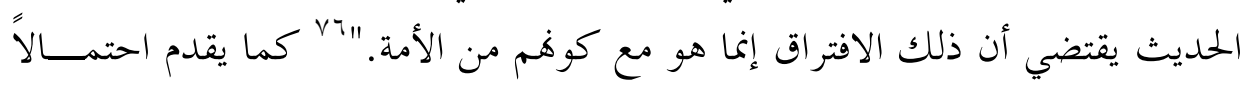

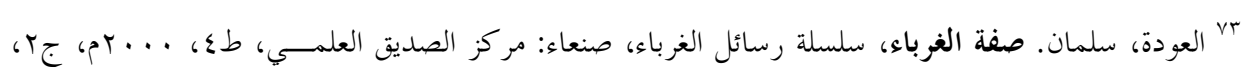

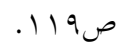

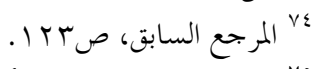

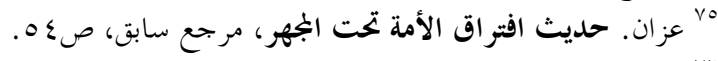

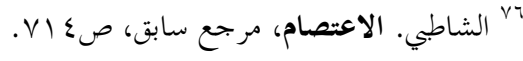




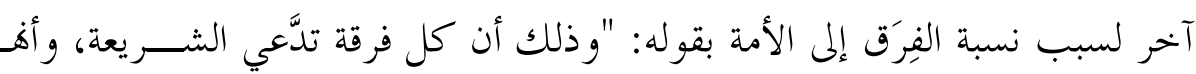

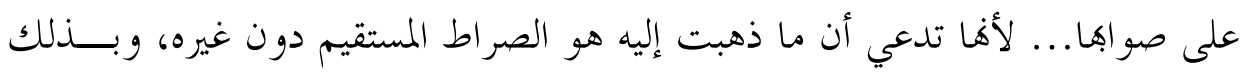
يخالفون من خرج عن الإسلام.

يقول الإمام الهادي (أحد أئمة الزيدية): "وأن قد حرم الله على المسلمين أن يزكوا

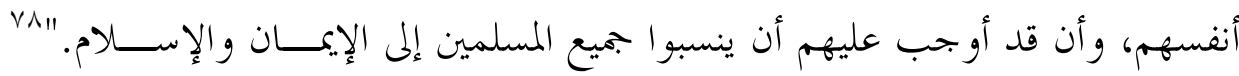

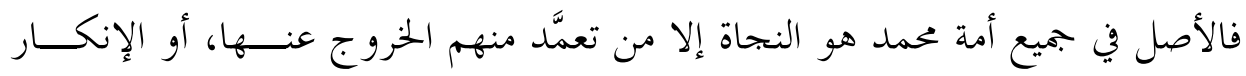
لمعلوم من الدين بالضرورة، أو أبى طاعة الله ورسوله.

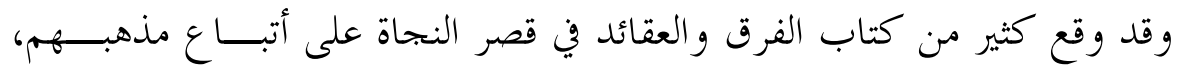

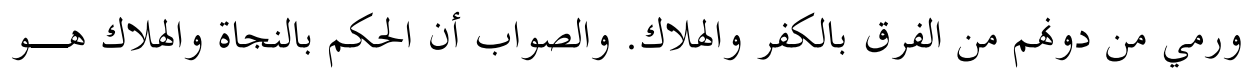

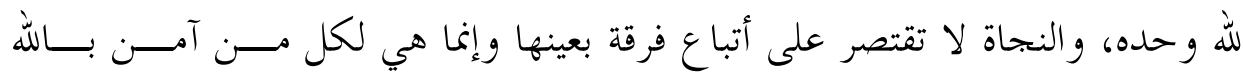

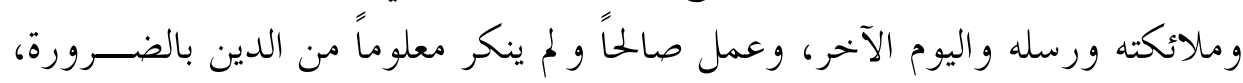

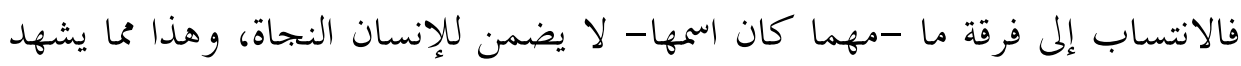

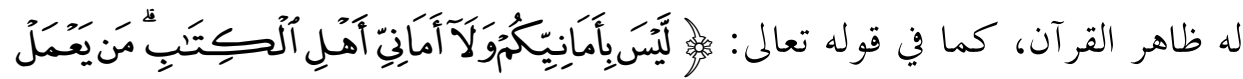

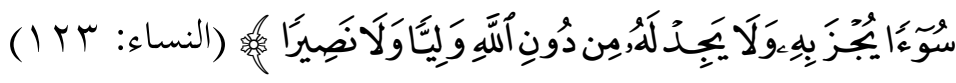

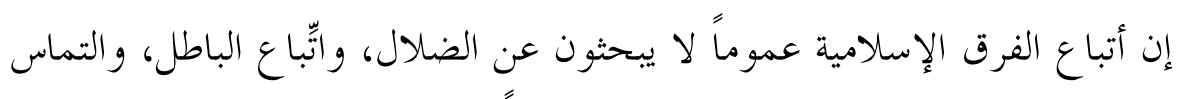

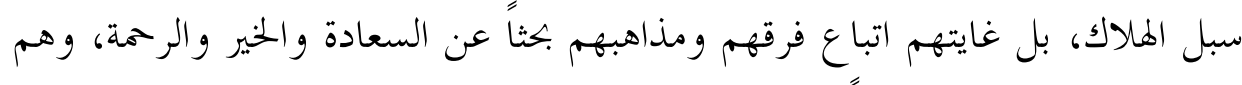

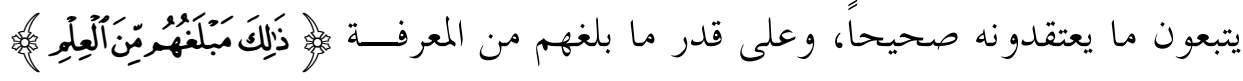

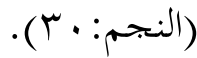

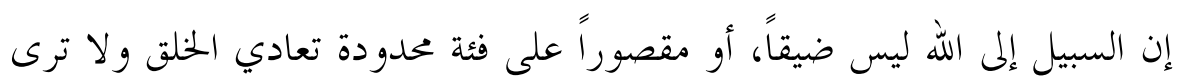

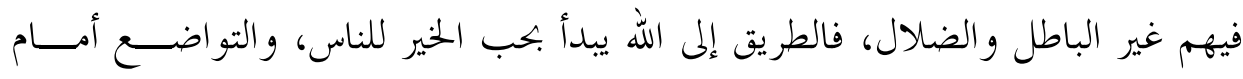

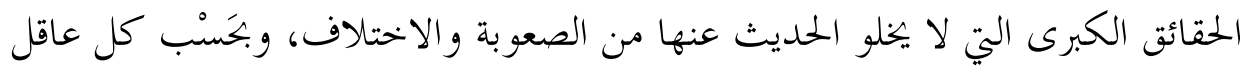

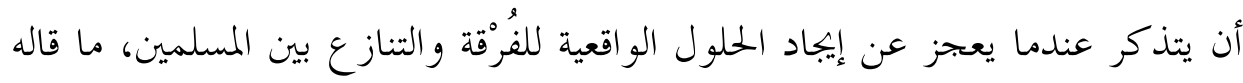




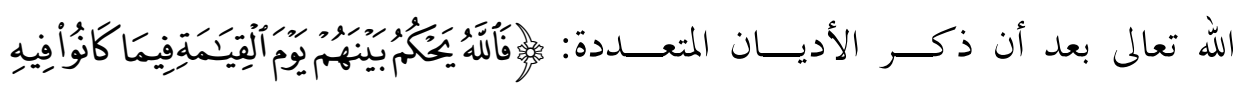

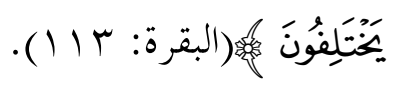

إن ادعاء النجاة لفئة من الناس دون غيرهم يتنافن مع العدالة الإلهيـــة والابــــاء

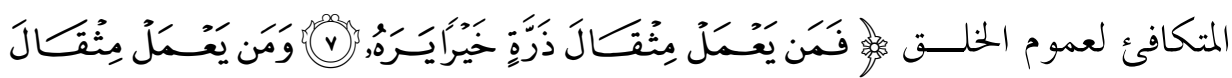

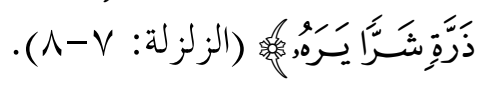

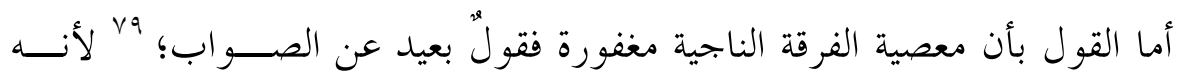

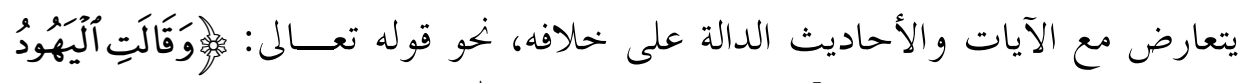

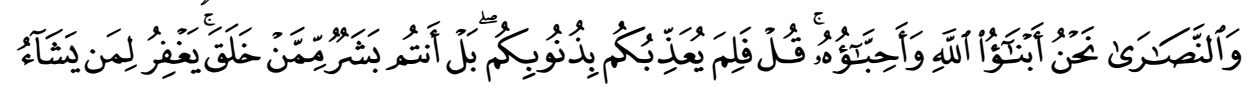

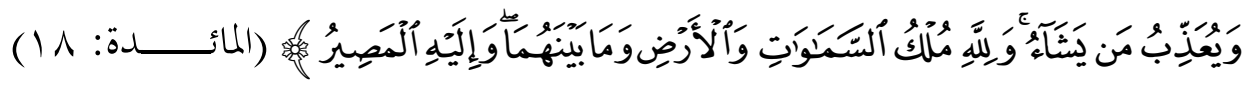

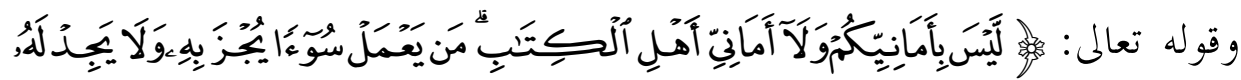

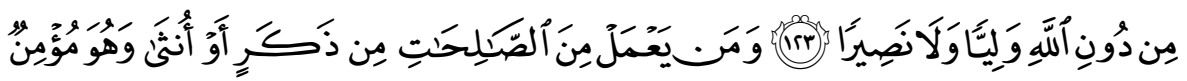

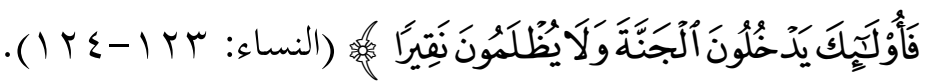
إن إقصاء الفرق المخالفة عن الدين إنما يعكس في أحد جو انبه النــزعة الانعز اليـــة و الإقصائية، التي تزداد حدة مع قلة المعرفة الموضوعية بالفرق المخالفة. و ماذا على هذه

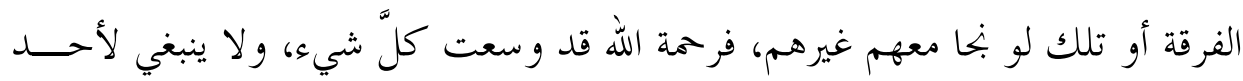

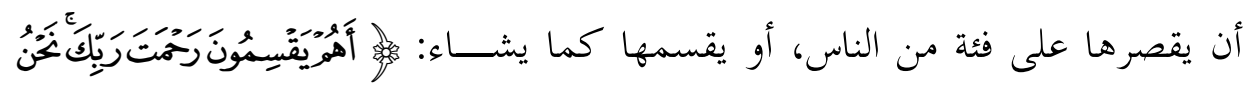

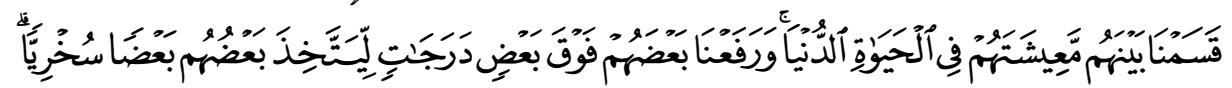

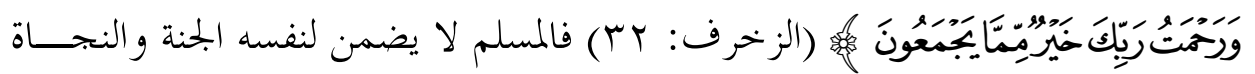
عندما يقضي على غيره بالهلاك، وإنما يستحق المسلم النجاة عندما يحب لأخيه ما يجبه لنفسه، و يتمىن له الصالح و النجاة، فالارتقاء إلى مستوى دفع السيئة بالحسنة، و مخالقة الناس بخُلقٍ حَسَنَ، هو الذي يعطي لمشروع التقريب بين الفرق الإســـلامية أساســـهـ الأخلاقي ورو حه التوحيدية.

Pa المسير. مقدمة في دراسة الفرق الإسلامية، مرجع سابق، ص. rه. 


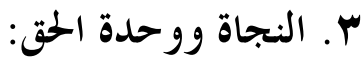

يذهب الشهرستاني إلى أن: "كل مسألة يتعين الحق فيها بين المتخاصمين فهي من

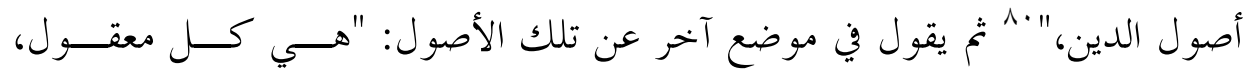
ويتوصل إليه بالنظر والاستدلال،" ای فهذا يدل على أن تعيّن الحق بين الفِرَق الإسلامية هو خاضع للنظر و الاستدلال.

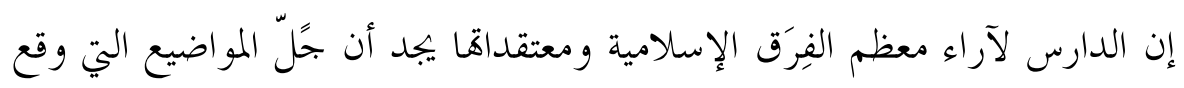

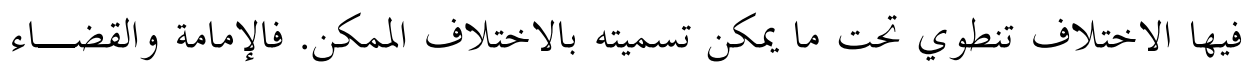

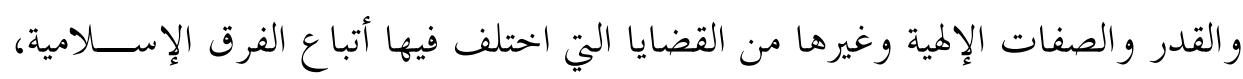

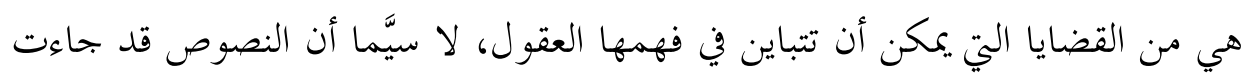
حَمّالة أوجه في معظمها.

وليس كل مخالف مناقض بالضرورة، يقول الراغب الأصفهاني: "ليس كل مختلفين

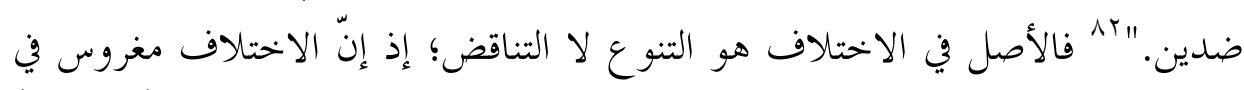

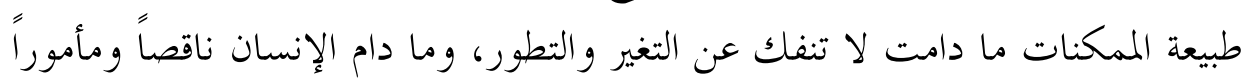

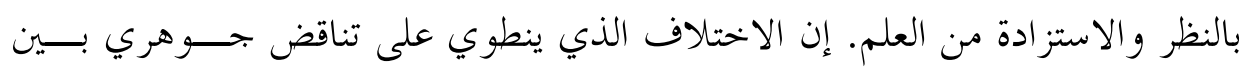

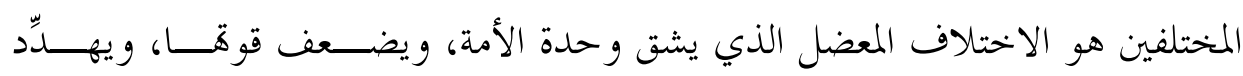

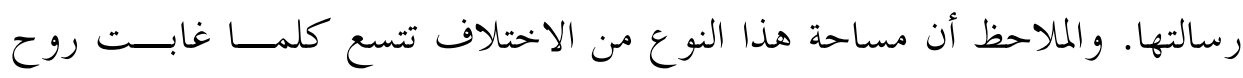
الوحدة و التراحم بين أبناء الأمة وضعف إحساسها برسالتها.

إنّ إعادة النظر في فحوى مقولة "الحق و احد وهو مع فرقة واحدة بعينها"، يُعـــُّ

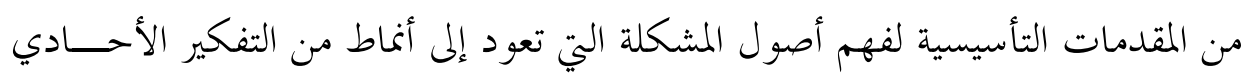
و الإطلاقي، الذي يغلب على عقول معظم الناس. إنّ الاغترار بالحق يمثـــل منـــــــــلقاً

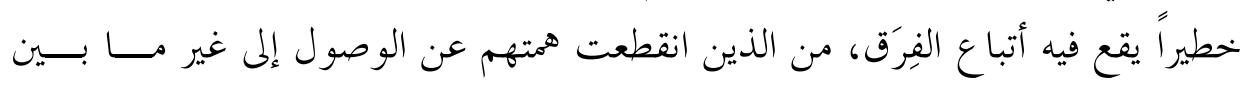

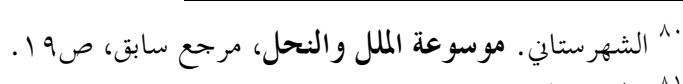

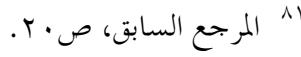

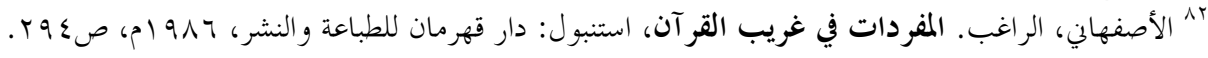


أيديهم من المعرفة، وهؤلاء يقعون بقصد أو دون قصد في تقديس آرائهم ومقـــــلاتهم،

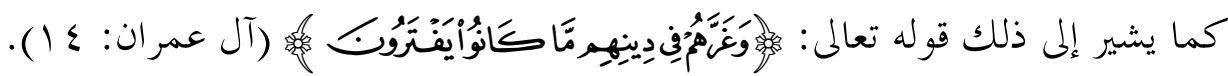
ومن يتعمق في دراسة تاريخ المعتقدات الدينية عند الشعوب لا يكاد يشك في أن

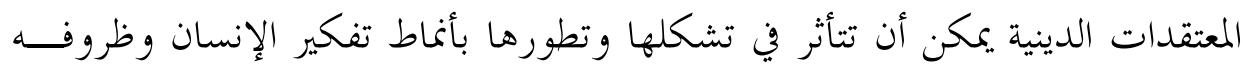

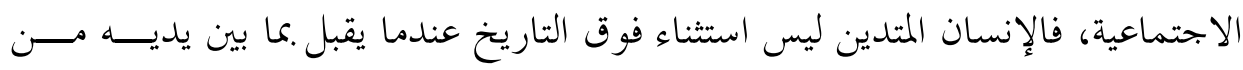

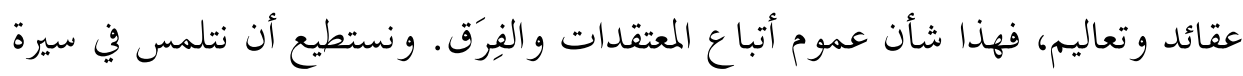

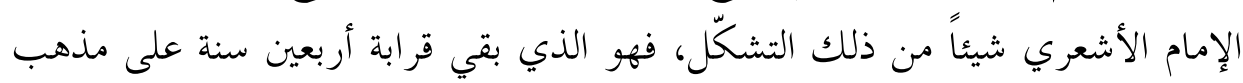

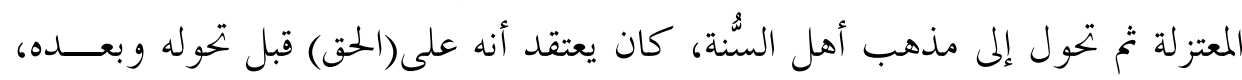

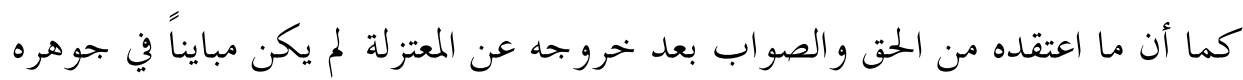
للحق الذي مات عليه الزخشري أو القاضي عبد الجبار. و خحلافاً للنــزعة الوثوقية الإطلاقية، التي تطغى على كثير من الكتابات المعاصرة،

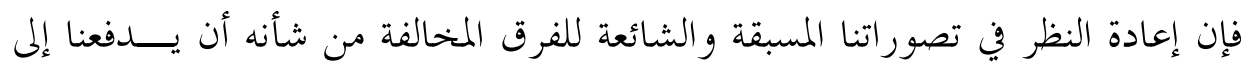

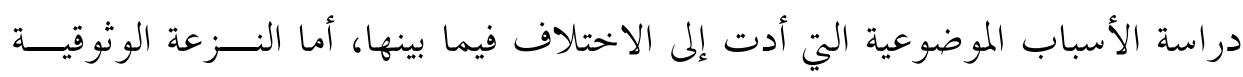
التي لا ترى في الأشياء غير تصورات مسبقة فترى إعادة النظر في تلك التصورات ألتئ أمراً

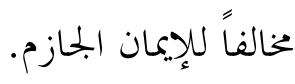
يمثل الشك العلمي منطلقًا أساسياً لدراسة الفِرق بعيداً عن النــزعة الوثوقية الــتي

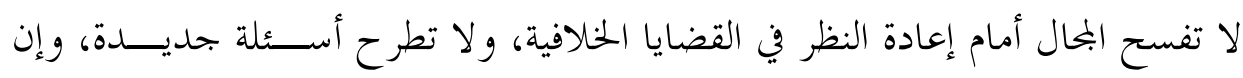
طرحت فإنا في الغالب لا تنتظر الإجابة من غيرها.

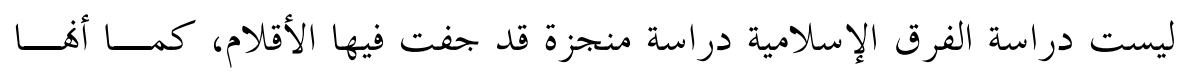

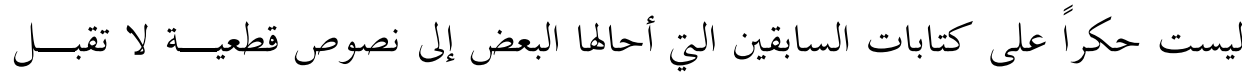

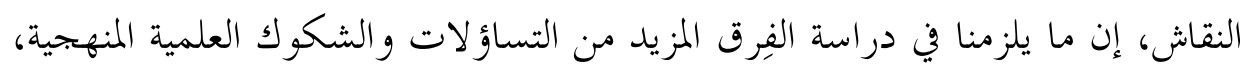

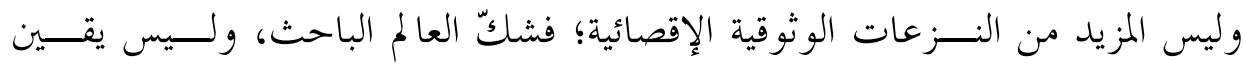
الجاهل الساذج، هو الكفيل بإعادة النظر في تلك الأحكام التي صاغها أتباع كل فرقة

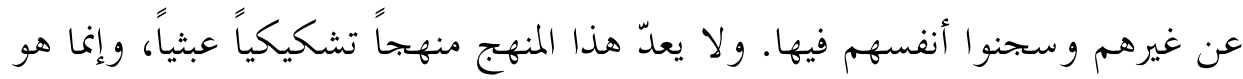




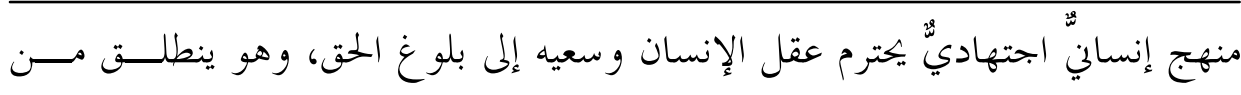

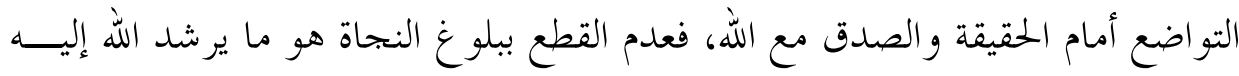

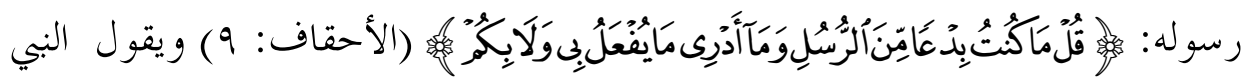


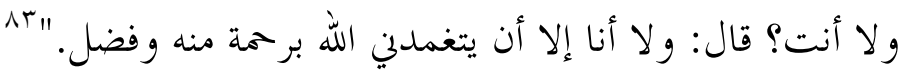
إنَّ معظم الدراسات و الكتابات حول الفِرقَ قد طغت عليها النـــــــعة الجحدليـــة

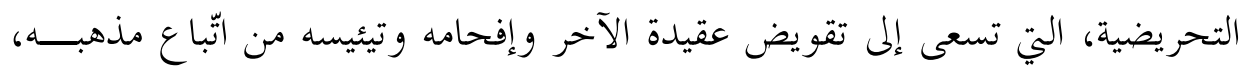

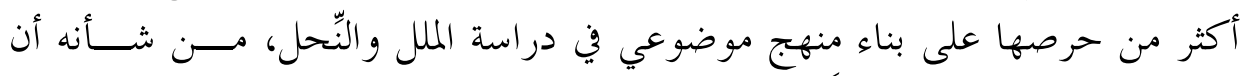

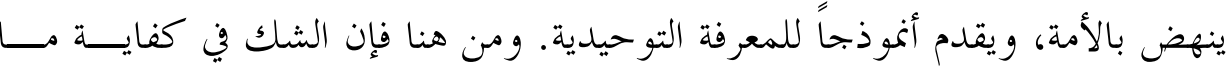

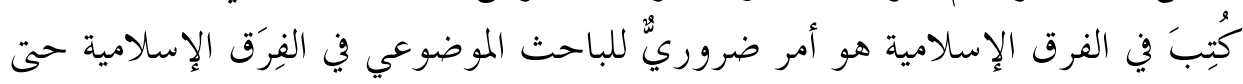
نستطيع الخروج من هذه الأزمة.

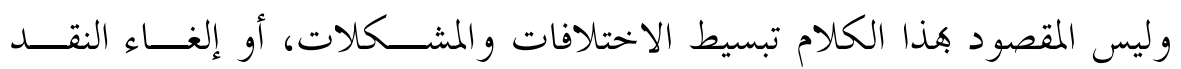

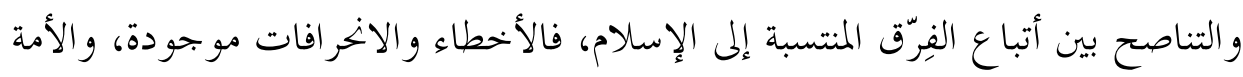

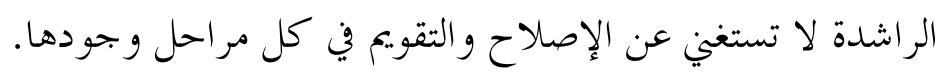

\section{سادساً: وحدة الأمة مقصد من مقاصد الشريعة}

إذا كانت الشريعة كما يقول ابن القيم "مبناها و أساسها على الحِكَـــم ومصــــالح

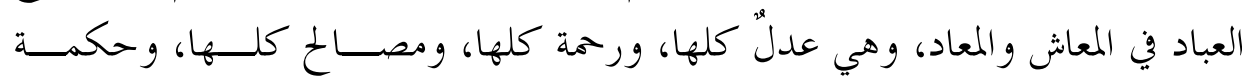

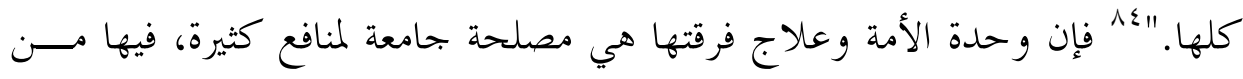
الحلكم و الرحمة ومصالح العباد ما لا ينكره عاقل.

كما تتضمن وحدة الأمة درءاً لمفاسد عظيمة، ورفعاً لضرر كبير يلحـــق بالأمـــة المقسمة المتنازعة، و حفظاً للأمة ولدينها من التفسخ و الانقسام، وعصمة لدماء لدماء أبنائها، وتوجيهاً لعقولهم وطاقاهم إلى ما يخدم البشرية ويخفظ مقوماها الروحية و والمادية.

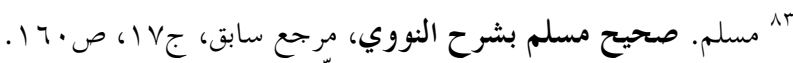

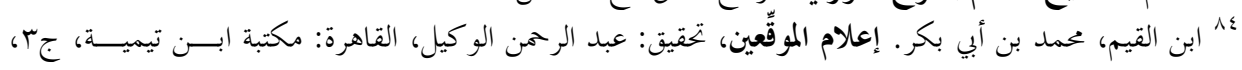




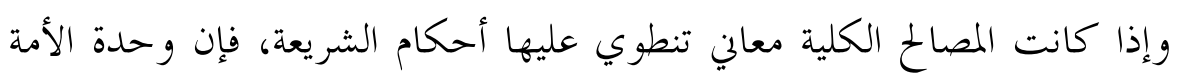

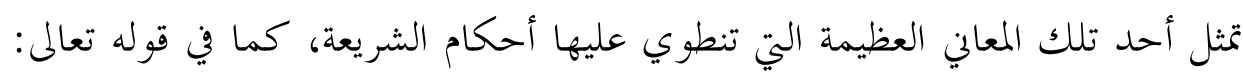

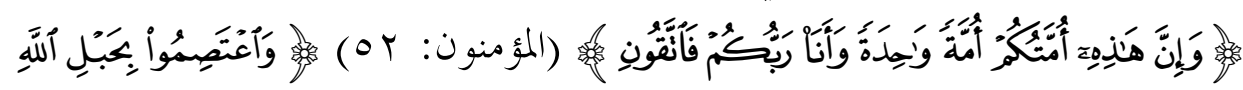

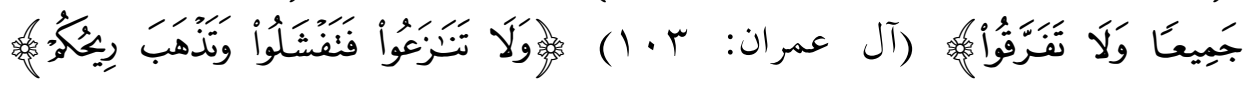

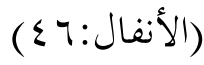

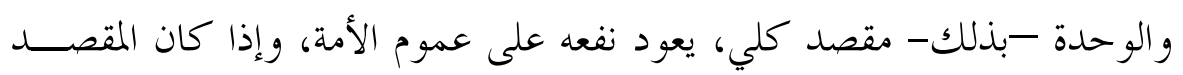

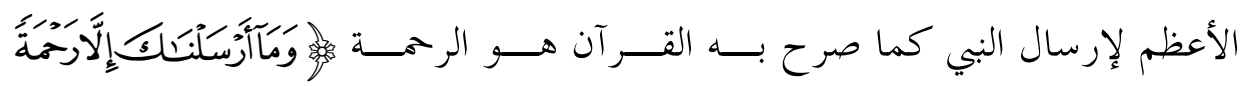

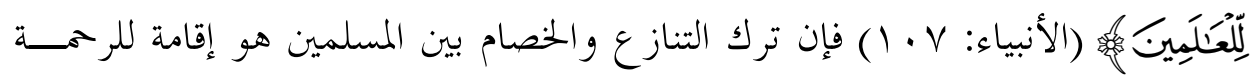

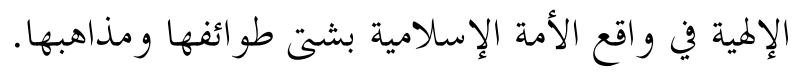

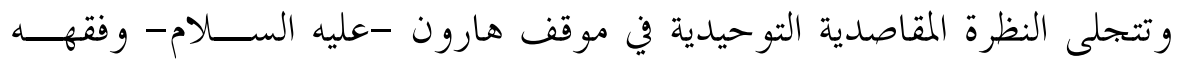

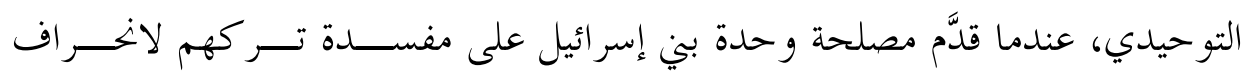

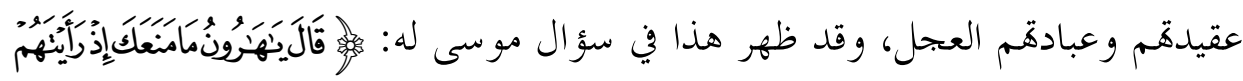

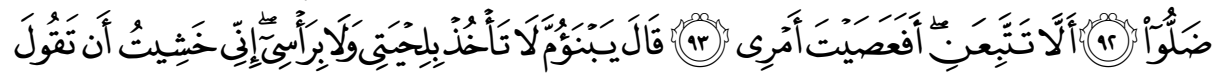

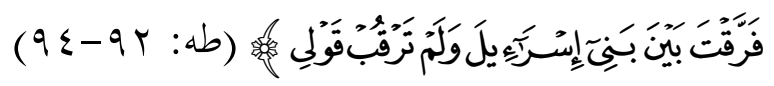

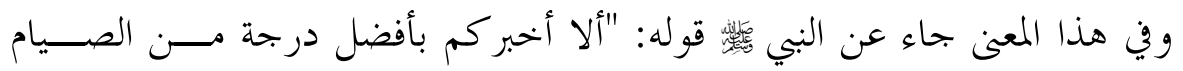

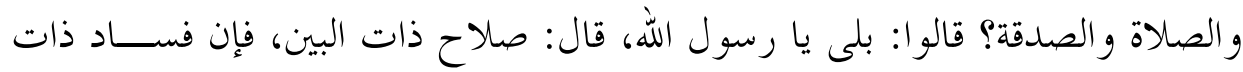

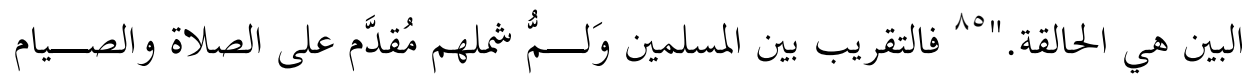

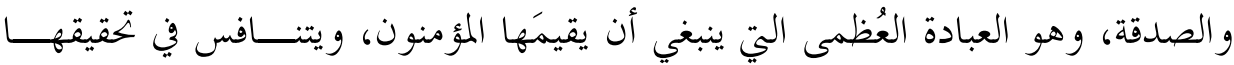

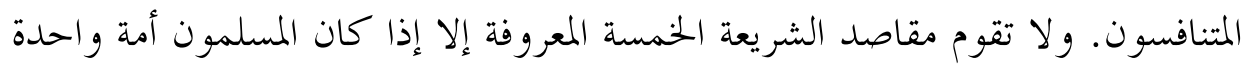

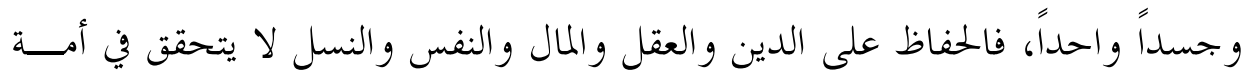

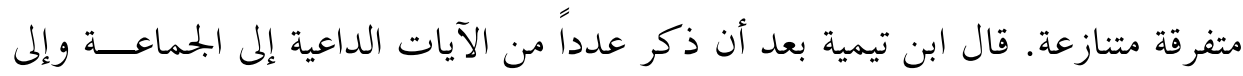

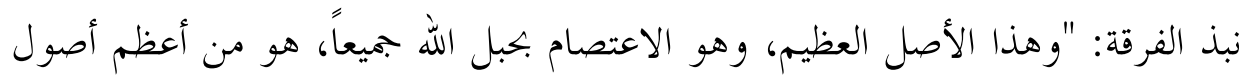

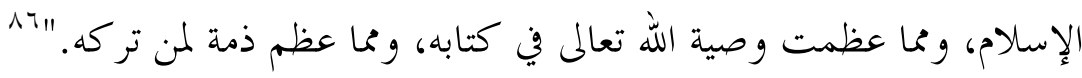

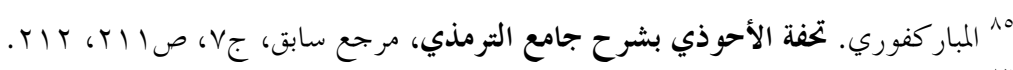

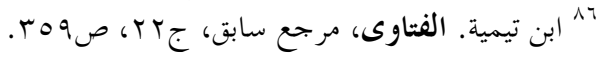




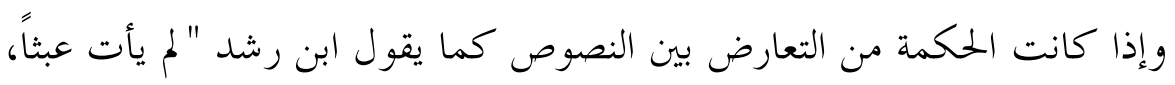

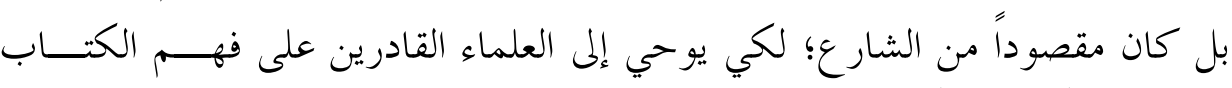

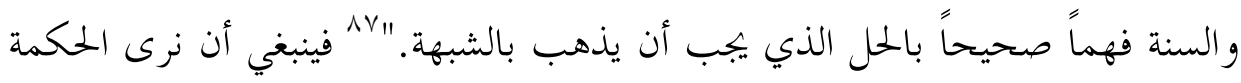

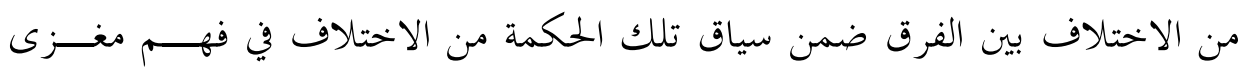

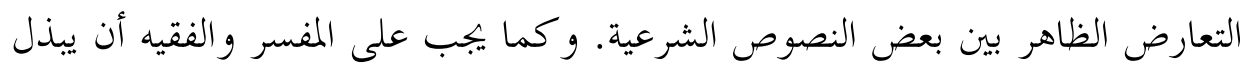

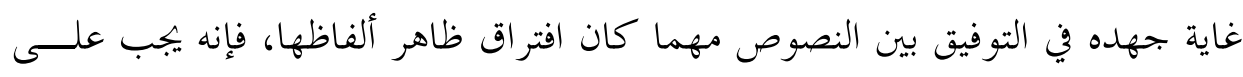

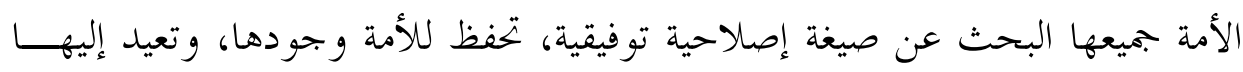
وحدةا مهما كان ظاهر اختلافها.

\section{سابعاً: الفِرَق الإسلامية بين النظرتين التوحيدية و التفسيخية}

ا ـ أبرز سمات النظرة التوحيدية لدراسة الفرق الإسلامية:

\section{أ. المراجعة النقدية للذات:}

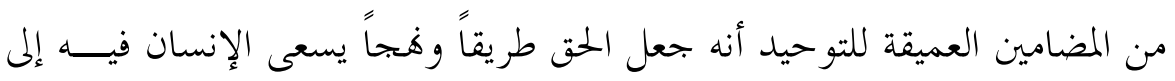

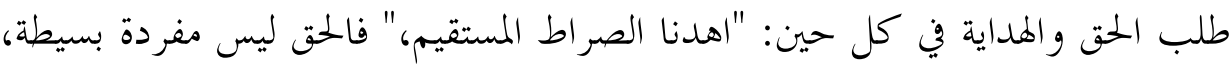

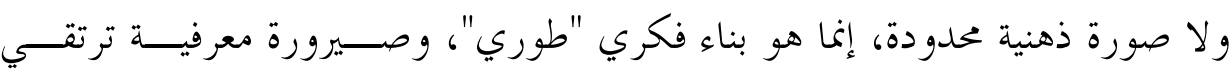

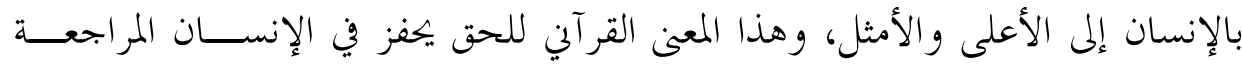
الدائمة لمو اقفه وتصور اته حيال ذاته أولاًا وبتحاه أخيه ثانياً.

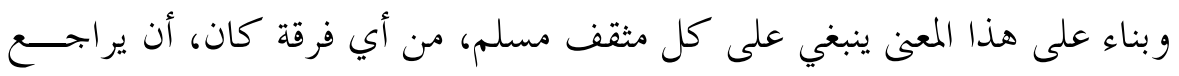

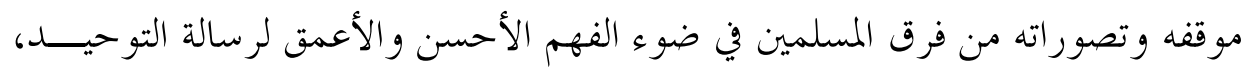

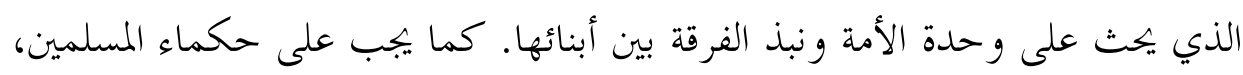

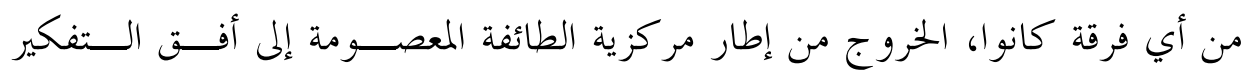

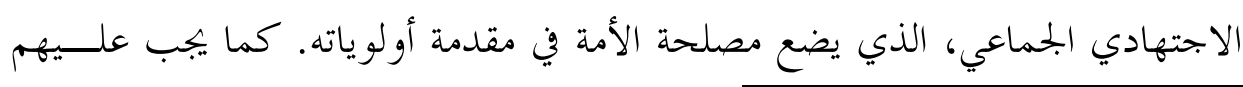

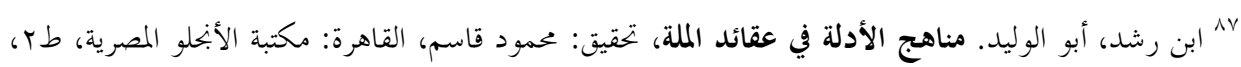




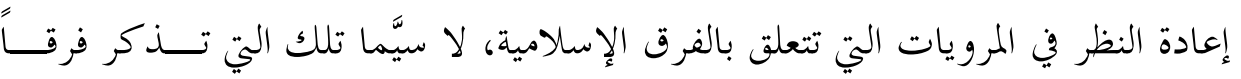

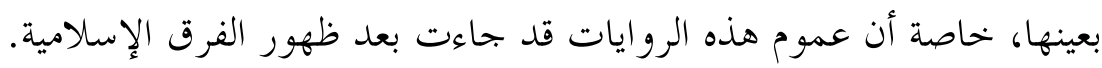

\section{ب. الانطلاق من القطعيات:}

الانطلاق مما يتفق عليه معظم علماء الأمة الذين يقرّون العقائد بالنصوص قطعيـــة

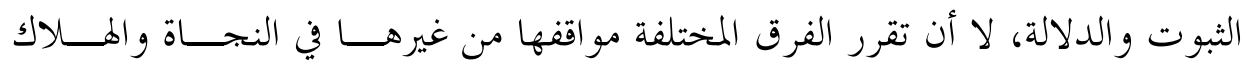

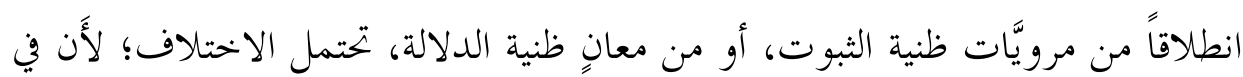

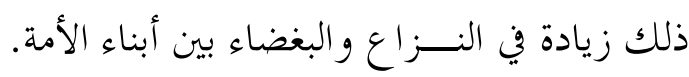

$$
\text { - - }
$$

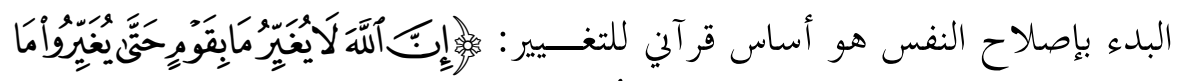

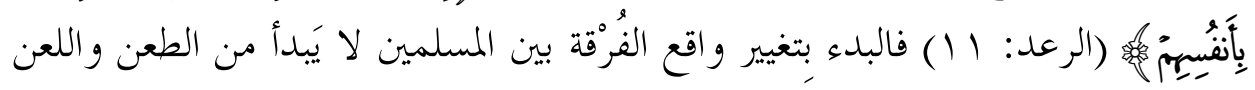

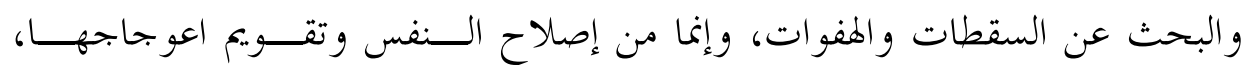
و الحكمة من ذلك هي تقلديم الأنموذج الأسمى ليكون أسوة للناس أجمعين.

$$
\text { - النصح وليس الوصاية: }
$$

النصح وعدم ادعاء الوصاية على الآخرين يقرب بين قلوب المؤمنين، وإذا كـــان

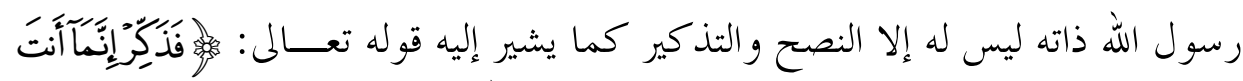

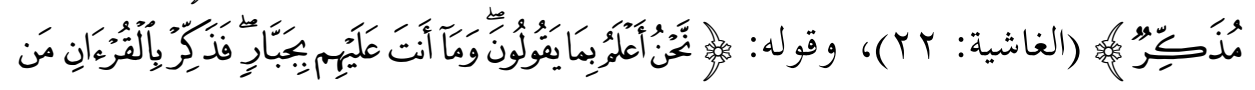

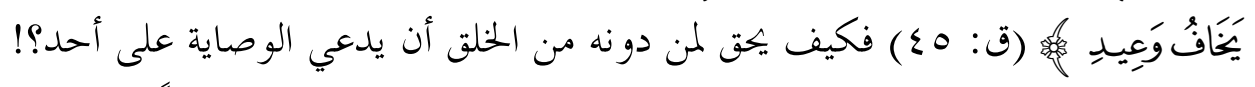

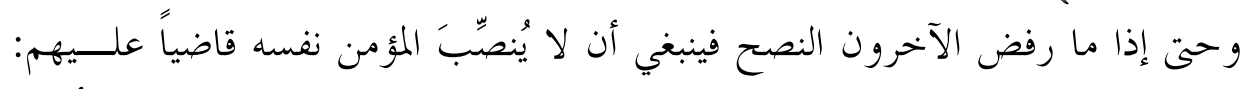

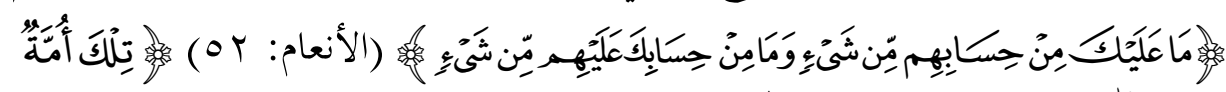

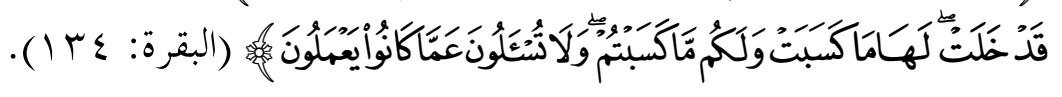
فالقرآن قد هانا عن الخوض في حقائق إيمان من سبقنا من أتباع الأنبياء السابقين،

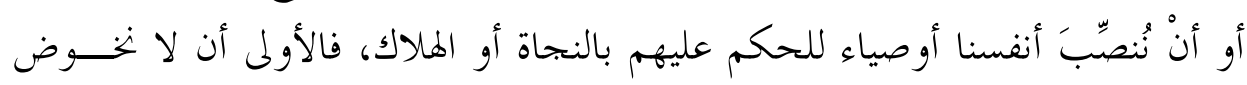




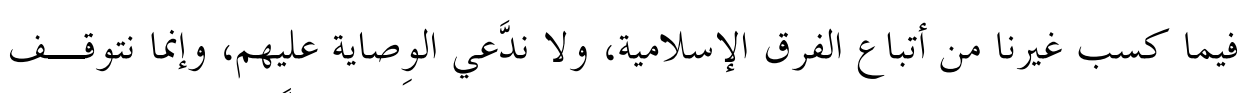

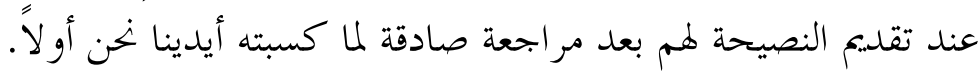
- المساو اة وعدم ادعاء الخصو صية عند الله:

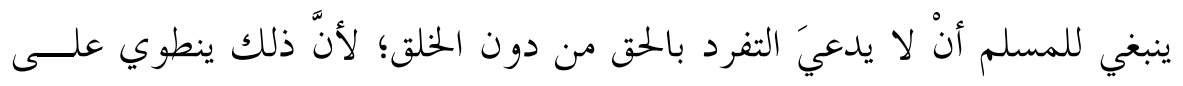

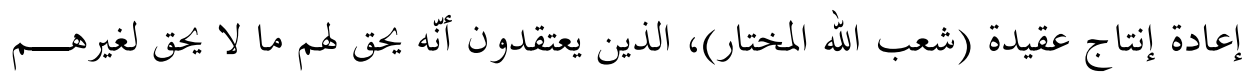

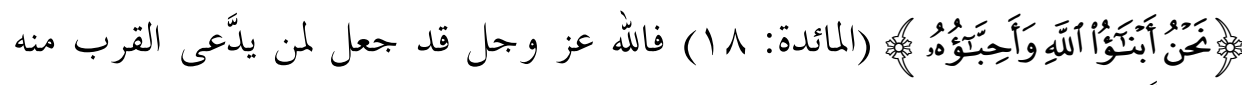

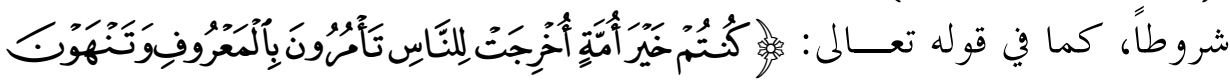

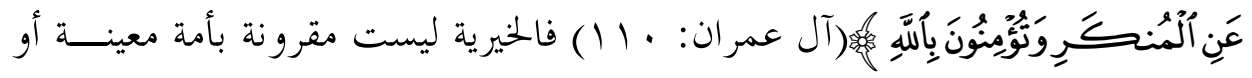
بطائفة خخصوصة، وإنما هي جملة من الأعمال والأخلاق التي يعيشها الإنسان. و وادعـــاء

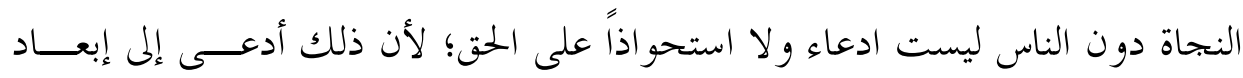
الآخرين وتيئيسهم من سعة رحمة الله، فالخِيِر مَنْ كان خيره للناس، و الأوْلى بالنجاة هو

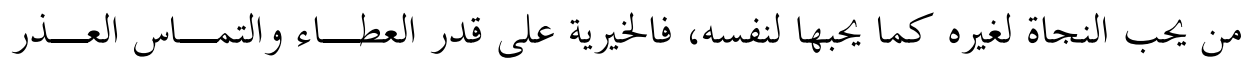
للآخرين، واللام في قوله تعالى (خير أمة أخرجت للناس) خير دليل على ذلك. - - الوحدة هي الأصل:

الانطلاق من "الوحدة الأصلية" يمثل قاعدة أساسية للتقريب بين المختلفين، قـال

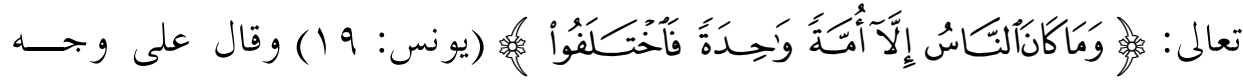

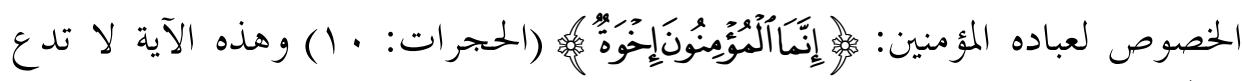

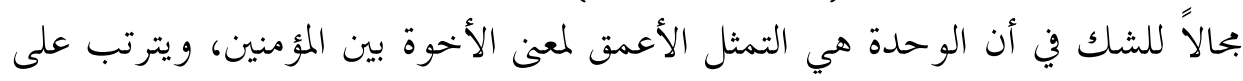

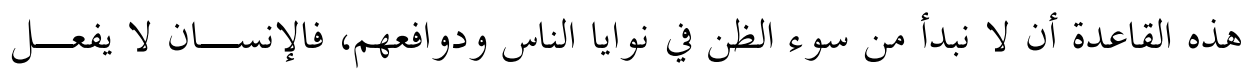

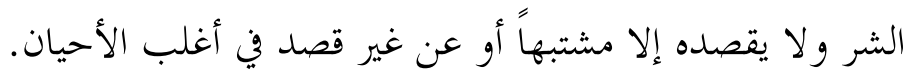

$$
\text { - }
$$

ضرورة تحرر المسلم من التقليد و الجهال حتى يستطيع فهم حقيقة غيره على ما هي

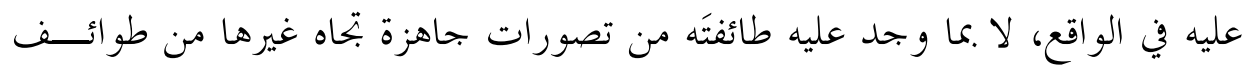


المسلمين:

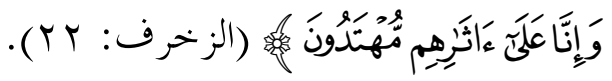

\section{Y. أبرز سمات المنهج التفسيخي في دراسة الفِرَق:}

$$
\text { أ. البحث عن كلمة السوء: }
$$

خلافاً لما أرشد القر آن المؤمنين إليه من الدعوة إلى "الكلمة السَّو اء" حتى مع غــير

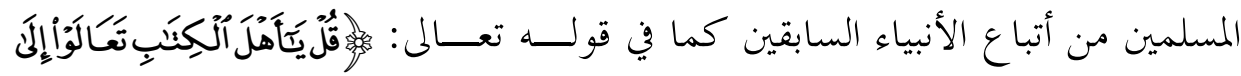

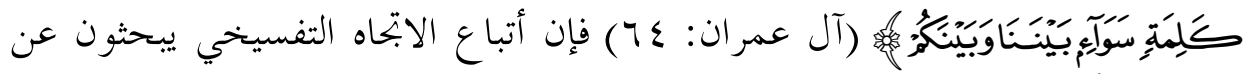

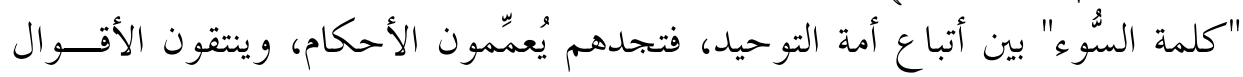

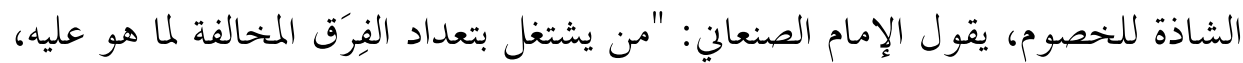

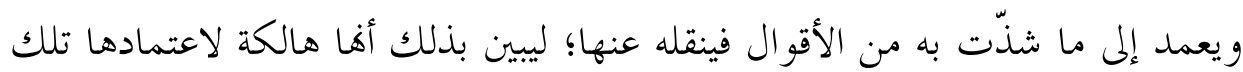

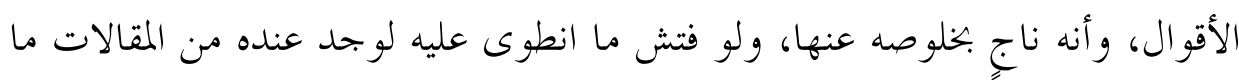

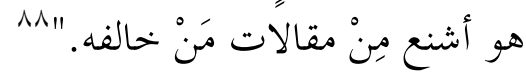

ومن الأمثلة الواضحة في البحث عن السَّقطات و الثغرات في كتب الخصوم تلــك

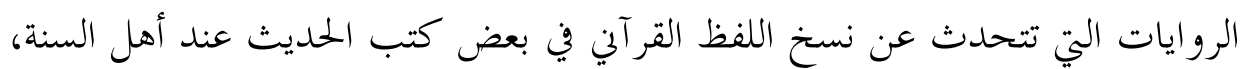
أو الروايات التي تتحدث عن مصحف فاطمة في بعض كتب الشيعة. ب. الاستهانة و الاستخفاف بالآخر:

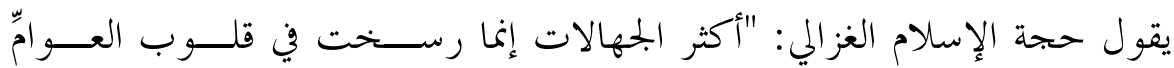

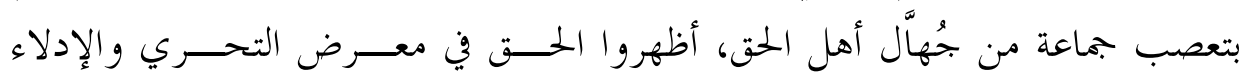

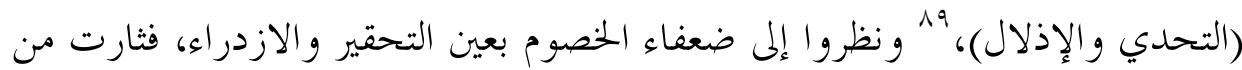

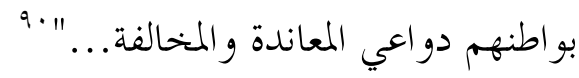

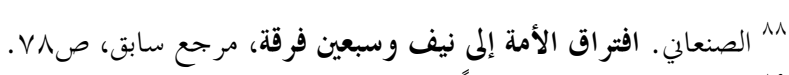

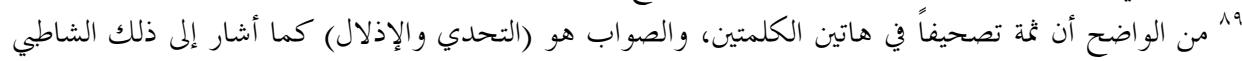
في استشهاده هذا النص في كتابه:

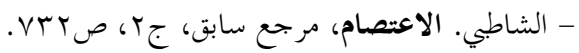

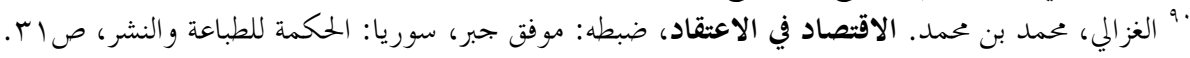




$$
\text { ت. الفهم الذَّرِي للنصوص: }
$$

و تتجلى هذه المشكلة من خلال التعامل مع كل نص أو رواية في كتب الخصـــوم

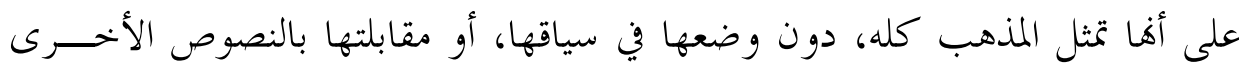
المتعلقة بالموضوع ذاتِهِ في سائر كتبهم.

ث. تضخيم الأسباب العقدية للاختلاف وإغفال الأسباب الأخرى:

تضخيم الأسباب الدينية و العقدية للاختلاف يزيد من حدة الافتــــاق، ويضــلل

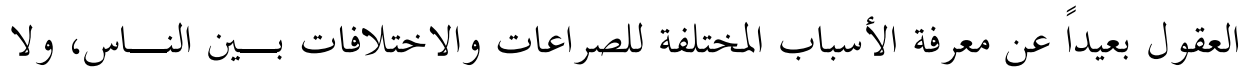

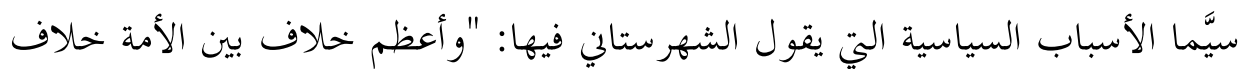

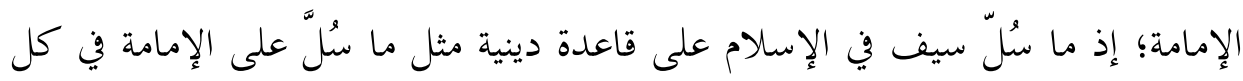

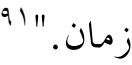

ج. عدم التفريق بين الأصل الديني والأصل المذهبي:

التفريق بين الأصل الديني العام والأصل المذهبي الخاص يمثل أساساً لصياغة مفهوم

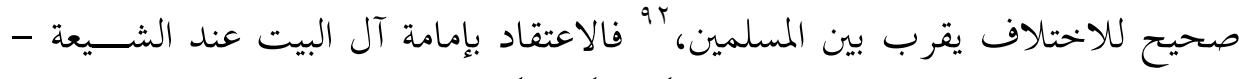

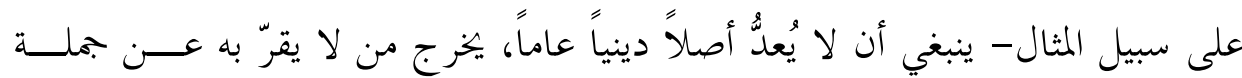

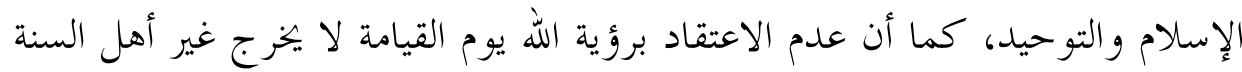
عن التوحيد.

\section{ح. المفهوم الضيق للاختلاف:}

إن النظر إلى تعدد الآراء بين الفرق الإسلامية من خلال مفهوم الاختلاف المذموم

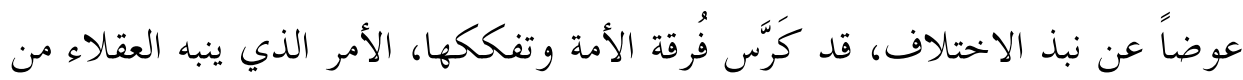

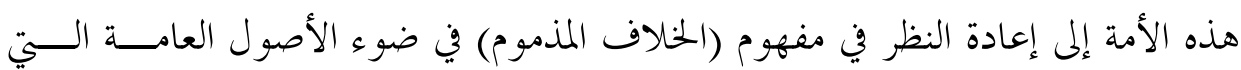

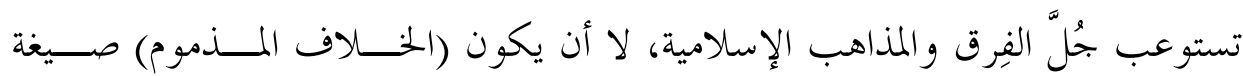


مذهبية وطائفية تقطع الطريق أمام أية مراجعة جادة لإعادة النظر في مواقف الفرق بحاه

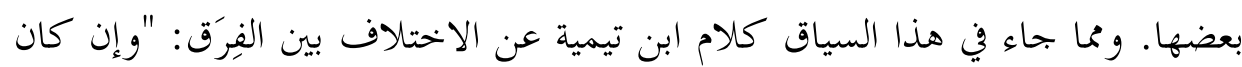
بعض ذلك (الاختلاف) مغفوراً لصاحبه؛ لاجتهاده الذي يغفر فيه خطؤه، أو لحسناته

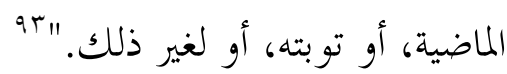

لا يمكن للباحث المنصف أن يصف كل اختلاف في العقائد بأنه اختلاف مذموم،

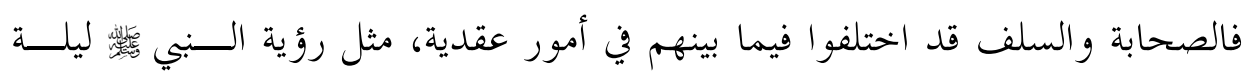

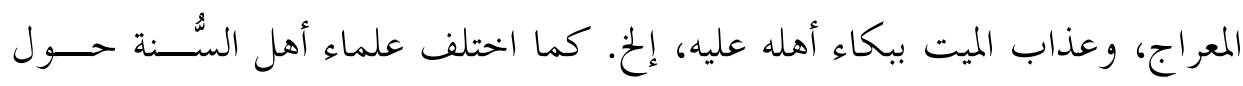
تعريف الإيمان وزيادته ونقصانه، واختلف الإمام أحمد مع الشافعي في مسألة تكفــير تارك الصالاة، وغير ذلك من القضايا.

يذهب ابن تيمية إلى أن الاجتهاد قد وقع لكثير من سلف الأمة في مقالات قالوها

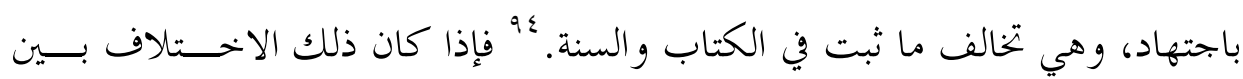

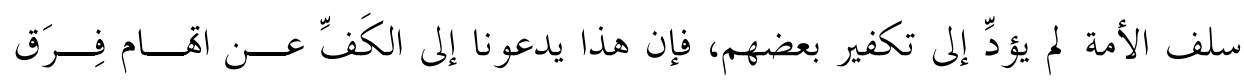

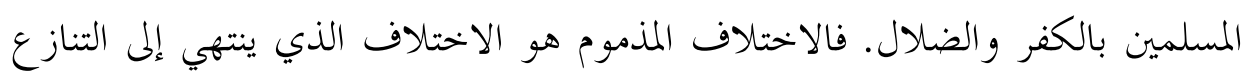

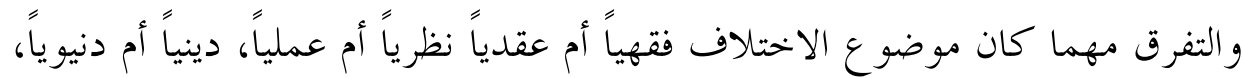
فليست العبرة بموضوع الاختلاف بقدر ما هي عاقبة الاختلاف وأثره.

خاتمة:

يلاحظ الدارس لحديث (افتراق الأمة) اضطراب روايات الحلديث، وعدم خلـــو

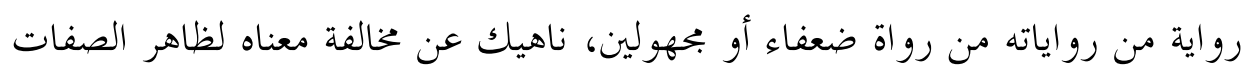

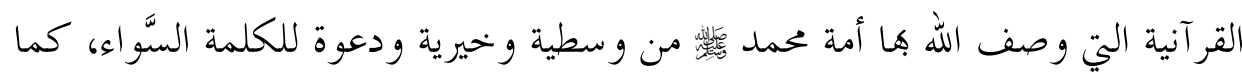

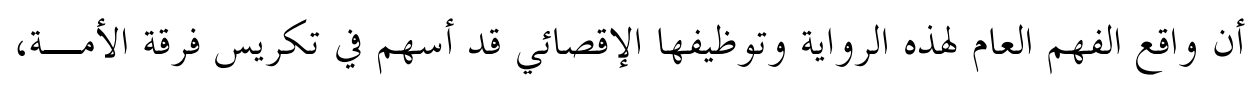
وزيادة تعصب كل فرقة لذاها، ورميها لغيرها بالكفر والهلاك. ولك.

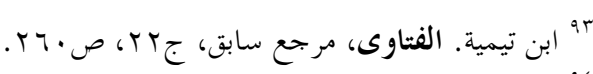

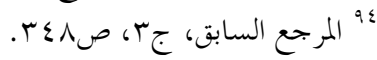




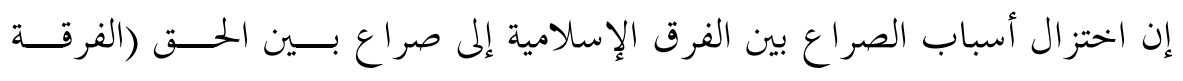

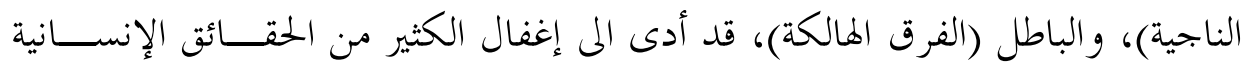

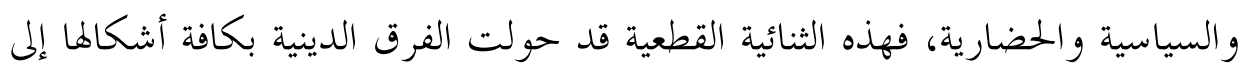

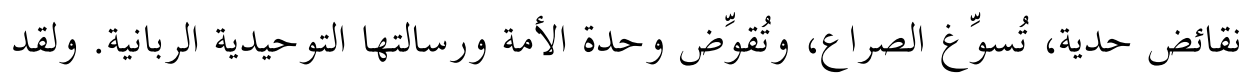

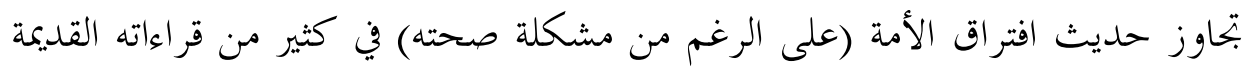

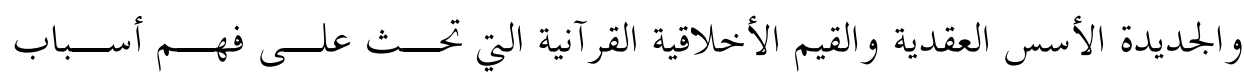

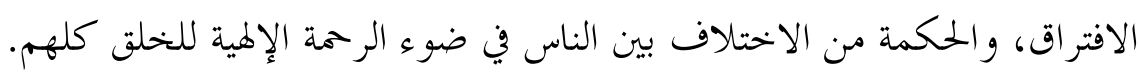
إن القراءة التوحيدية لحديث (افتراق الأمة) يقتضي العمل على امتثال ما جـــاء في

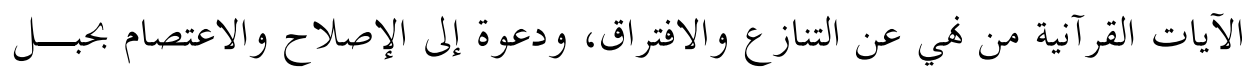

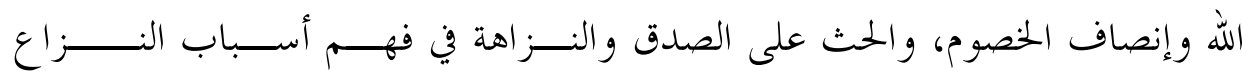

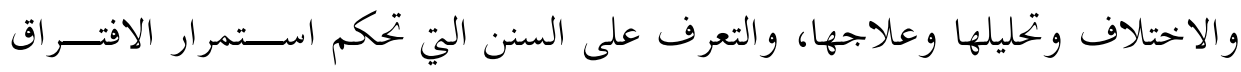

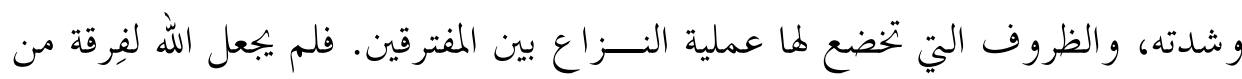

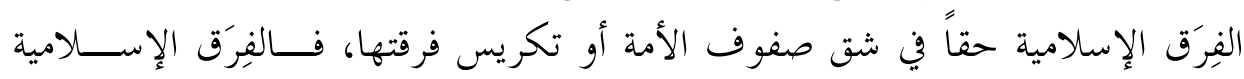

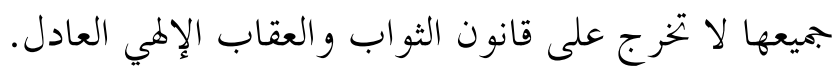

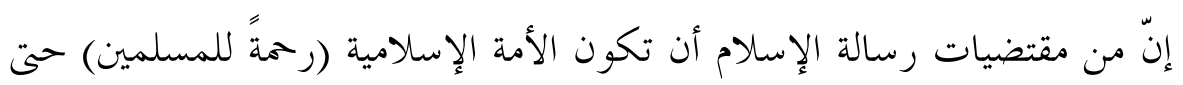

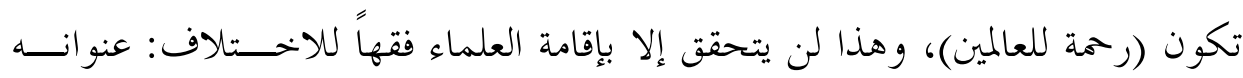

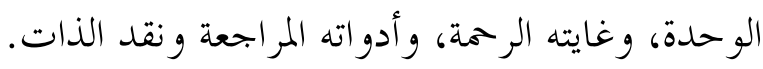

